\title{
Community metabolism and energy transfer in the Chesapeake Bay estuarine turbidity maximum
}

\author{
Dong Y. Lee ${ }^{1, *}$, David P. Keller ${ }^{2}$, Byron C. Crump ${ }^{1}$, Raleigh R. Hood ${ }^{1}$ \\ ${ }^{1}$ Horn Point Laboratory, University of Maryland Center for Environmental Science, 2020 Horns Point Road, Cambridge, \\ Maryland 21613, USA \\ ${ }^{2}$ IFM-GEOMAR, Leibniz-Institut für Meereswissenschaften, Düsternbrooker Weg 20, 24105 Kiel, Germany
}

\begin{abstract}
In an effort to identify the key mechanisms controlling biological productivity and food web structure in the Chesapeake Bay estuarine turbidity maximum (ETM), we measured plankton community metabolism on a series of surveys in the upper Chesapeake Bay during the winter and spring of 2007 and 2008. Measured quantities included primary production, bacterial production, planktonic community respiration, and algal pigment concentrations. These measurements revealed a classic minimum in photosynthesis in the vicinity of the ETM. Temporal variability in plankton community metabolism, primary production, respiration, and bacterial production were highest in the southern oligohaline region down-estuary of the ETM and appeared to be driven by dynamic bio-physical interactions. Elevated primary production and community respiration in this region were often associated with the presence of mixotrophic dinoflagellates. The dinoflagellate contribution to primary production and respiration appeared to be particularly large as a result of their mixotrophic capabilities, which allow them to obtain energy both autotrophically and heterotrophically. The present study suggests that mixotrophic dinoflagellates play a key role in the pelagic food web in the oligohaline region of Chesapeake Bay, supplying most of the labile organic matter during late winter and spring and also providing a vector for transferring microbial production to mesozooplankton.
\end{abstract}

KEY WORDS: Estuarine turbidity maximum - Plankton community metabolism · Mixotrophic dinoflagellate $\cdot$ Estuarine food web $\cdot$ Chesapeake Bay

\section{INTRODUCTION}

Chesapeake Bay is the largest estuary in the United States, and the Susquehanna River at the head of the bay is responsible for $>50 \%$ of freshwater input (Kemp et al. 2005). There is a distinct seasonal pattern in river flow, with high discharge from late winter to spring and low to moderate discharge from summer to fall. The flow largely controls salinity gradients and therefore stratification, pycnocline depth, and the location of the turbid zone (Schubel \& Pritchard 1986). The highest concentration of suspended particles is usually found at the limit of salt intrusion in the vicinity of the sharp salinity gradient where freshwater and seawater converge. This region, called the estuarine turbidity maximum (ETM), occurs in a channel that is maintained by dredging. Gravitational circulation induced by the composite influence of tidal exchange and freshwater discharge generates 2-layer circulation and entraps particles in the ETM. The trapping is primarily due to the convergence and recirculation at the freshwater/saltwater interface, but it is also influenced by a variety of factors such as stratification, resuspension, flocculation, tides, settling velocity, sedimentation rate, topography, and wind (Sanford et al. 2001).

The oligohaline area of the bay, where the ETM is located, encompasses $11 \%$ of the total bay area and receives organic matter from both terrestrial and 
aquatic sources. Estimating the quantity and quality of this organic matter is difficult due to the diverse origins and complex biogeochemical reactions that occur between dissolved and particulate organic matter and living organisms (Simon et al. 2002). In lakes, stable isotope analysis of organic carbon indicates that a greater fraction of heterotrophic metabolism is fueled by terrestrial organic matter than by autochthonous primary producers when environmental conditions limit autotrophic production (Carpenter et al. 2005, Pace et al. 2007). In Chesapeake Bay, primary production and chlorophyll a $(\mathrm{chl} a)$ concentrations are lowest in the oligohaline area (Smith \& Kemp 1995), presumably due to light limitation (Fisher et al. 1999), suggesting that, as in lakes, terrestrial organic matter plays an important role in heterotrophic production.

Understanding the relative importance of autochthonous algal production compared to allochthonous input in the ETM is particularly important because this region is an area of high larval recruitment for many fish species including striped bass Morone saxatilis and white perch $M$. americana (North \& Houde 2006). Mesozooplankton such as the calanoid copepods Eurytemora affinis and Acartia tonsa and the freshwater cladoceran Bosmina longirostris are also very abundant (Roman et al. 2001). Elevated mesozooplankton biomass during periods of high freshwater flow enhances larval fish production (Kimmel \& Roman 2004), but the sources and pathways of organic matter fueling mesozooplankton production are unknown.

One potential source of organic matter for mesozooplankton in the ETM is suspended detritus. As a part of a dynamic food web, the microbial loop theory emphasizes the importance of detrital production pathways (Pomeroy 1974, Azam et al. 1983). Expanding on this theory, Baross et al. (1994) proposed the 'microbial shunt', which theorizes that, if bacteria and detritus are directly consumed by copepods, the shortened production pathway would result in higher energy conservation and transfer efficiency than the microbial loop. The shunt theory is in part supported by the effective grazing capability of many copepods on a broad size spectrum of prey items (Heinle et al. 1977, Boak \& Goulder 1983). However, this unique pathway would not result in high copepod production if the quantity and quality of detrital organic matter limits the growth of copepods.

Direct measurements of oxygen changes provide a tool for estimating the relative contributions of autotrophic and heterotrophic processes in aquatic systems and therefore quantifying the relative importance of autochthonous versus allochthonous carbon sources in the food web. Net ecosystem metabolism (NEM), estimated by subtracting community respiration $\left(R_{\text {comm }}\right)$ from gross primary production (GPP), can be used to assess the aggregate response of a wide variety of autotrophic and heterotrophic species in a community to environmental and anthropogenic influences which can reveal the trophic status of an ecosystem (Caffrey 2004). Estuarine eutrophication due to anthropogenic disturbances often causes negative NEM (also called net heterotrophy), implying that more organic matter is consumed by respiration than produced by autotrophic growth (Hopkinson \& Vallino 1995). In the oligohaline area of the bay, both GPP and $R_{\text {comm }}$ are low, but the latter exhibits high spatial and temporal variations because of differences in uptake rates and growth efficiency on terrestrial and autotrophic organic matter by heterotrophs (Smith \& Kemp 1995, 2003). In general, NEM in the oligohaline is net heterotrophic, though often with significant seasonal variations (Kemp et al. 1997) due to the high organic loads. In contrast, in areas where GPP is high due to abundant light and inorganic nutrients the ecosystem can have positive NEM (also called net autotrophy), implying that more organic matter is produced by local autotrophic growth than consumed by heterotrophic respiration.

Here we describe results from a series of temporal and spatial surveys in the Chesapeake Bay ETM region. These measurements provide insight into the metabolic demands of different plankton communities in relation to salinity and turbidity. We speculate that the balance between autotrophic and heterotrophic processes can vary significantly with time and in space, especially during late winter and spring, due to temporal variability in river flow. Although the ETM appears to play an important role in secondary production, the major sources of the organic matter that fuel higher trophic level production (e.g. freshwater, marine, local) are currently unknown. The objectives of the present study are to use direct measurements of primary production and respiration in combination with bacterial production (BP), water quality, and algal pigment data to (1) characterize the spatial and temporal variability in GPP and respiration, (2) determine which members of the phytoplankton community contribute to GPP that might fuel growth of higher-trophic-level organisms, and (3) compare GPP and BP to identify food web pathways through which production is transferred to higher trophic levels. 


\section{MATERIALS AND METHODS}

\section{Study site}

The present study was conducted on a $76 \mathrm{~km}$ axial transect along the main channel of the upper Chesapeake Bay from Turkey Point lighthouse (latitude: $39^{\circ} 26.9^{\prime} \mathrm{N}$; $0 \mathrm{~km}$ ) near the mouth of Susquehanna River to the Chesapeake Bay Bridge (latitude: $38^{\circ} 59.8^{\prime}$ N; 76 km), Maryland, USA (Fig. 1). River discharge data provided by United States Geological Survey were recorded at the Conowingo Dam located in the lower Susquehanna River (39³9'28.1" N, $76^{\circ} 10^{\prime} 28.2^{\prime \prime} W_{i}$ http://waterdata.usgs.gov/md/nwis) according to the methods of Buchanan \& Somers (1969). Hereafter, the oligohaline area is often segmented into 3 regions: (1) the northern region located from 0 to $30 \mathrm{~km}$ from the mouth of Susquehanna River to the landward side of ETM, (2) the ETM region located from 30 to $45 \mathrm{~km}$, and (3) the southern region located from 45 to $80 \mathrm{~km}$. A total of 6 cruises were con-

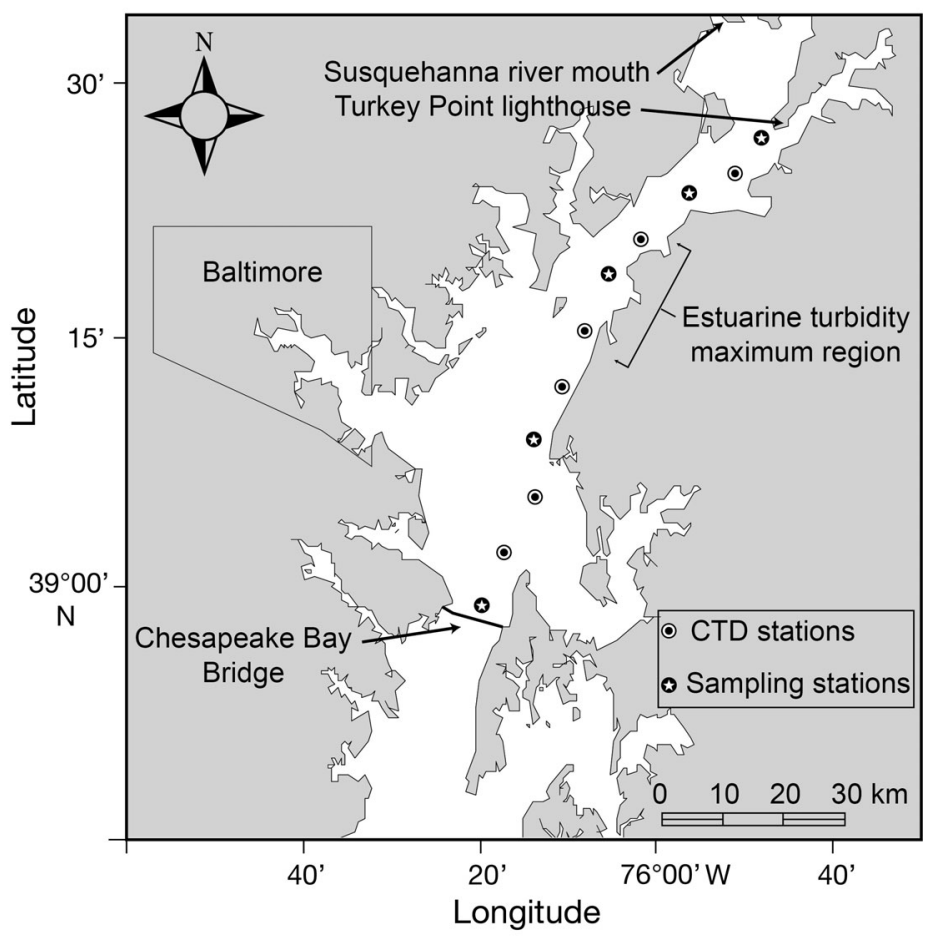

Fig. 1. The oligohaline area of Chesapeake Bay, which is approximately $80 \mathrm{~km}$ along a shipping channel and stretches from Havre de Grace (latitude: $39^{\circ} 28.3^{\prime} \mathrm{N}$ ) at the mouth of the Susquehanna River to the Chesapeake Bay Bridge (latitude: $38^{\circ} 59.8^{\prime} \mathrm{N}$ ), Maryland, USA. A CTD profiler was cast at 11 stations from the south to the north within $8 \mathrm{~h}$ from 06:00 to 14:00 h. Water samples were collected from 5 stations among the 11 stations. Sampling station positions are approximate ducted, (22 to 26 February 2007, 23 to 26 January 2008), 2 in early spring (9 to 15 April 2007, 17 to 23 April 2008), and 2 in late spring (8 to 14 May 2007, 16 to 22 May 2008) on the RV 'Hugh R. Sharp'. The spring cruises were designed to maximize observations during the time periods of high river discharge and organic matter loading. Two quasi-synoptic axial surveys were performed at the beginning and end of each cruise. These consisted of 11 CTD (Sea-Bird Electronics) casts equipped with fluorescence, oxygen, and optical backscatter sensors. All axial surveys were done in < $8 \mathrm{~h}$ from 06:00 to 14:00 h. Salinity and turbidity were mapped as contour plots, and it should be noted that the actual scale of the $x$-axis (river distance) to $y$-axis (depth) on the contour plots is distorted by about 300:1.

\section{Field sampling procedures}

Five stations out of the 11 CTD sites were selected along the axial surveys for water sample analyses. At each of these 5 stations, which included 2 stations in the north, 1 in the ETM, and 2 in the south, samples were collected for measuring plankton community metabolism, water quality, pigment analysis, and BP simultaneously with 201 Niskin bottles mounted on a CTD frame at $0.5 \mathrm{~m}$ below the surface, in the pycnocline, and $0.5 \mathrm{~m}$ above bottom. At the freshwater end-member (furthest up-estuary) station where there was no pycnocline, mid-water samples were collected at mid-depth. Under low light conditions we gently transferred water from each depth into 241 buckets equipped with a stir bar to ensure the homogeneity of water samples. At least $10 \mathrm{~min}$ after the transfer, samples for measuring oxygen production and consumption were siphoned through Tygon laboratory tubing into triplicate $60 \mathrm{ml}$ borosilicate biochemical oxygen demand (BOD) bottles, allowing each bottle to overflow 3 times its volume. Samples for initial oxygen concentration were fixed immediately. Oxygen concentration was measured using the Winkler titration method (Carpenter 1965), with an automated photometric endpoint detection system having a minimum precision of $0.01 \%$ (Sensoren Instrument System). The light-dark bottle oxygen method (Kemp et al. 1992) was used for making primary production and respiration measurements with samples incubated on rotating transparent and opaque flow-through incubators (12 rotations $\mathrm{min}^{-1}$ ) respectively, at ambient water temperature $\left( \pm 1^{\circ} \mathrm{C}\right)$ on shipboard, to prevent any biased rates due to settling of suspended material. 


\section{Primary production measurements}

Surface water samples were obtained from approximately $0.5 \mathrm{~m}$ below the surface between sunrise and midday ( 07:00 to 13:00 h). Then, BOD bottles were filled and covered with neutral-density screens allowing passage of 5 different light levels of surface irradiance, and they were incubated in a rotating deck incubator under sunlight for $24 \mathrm{~h}$. Underwater irradiance levels were measured using a PRR-600 PAR sensor (400 to 700 nm; Biospherical Instruments) or Secchi Disc depth following CTD casts. The Secchi Disc was used only in late spring 2008 when the radiometer malfunctioned. The Lambert-Beer Law was used to calculate diffuse attenuation coefficients and euphotic depths ( $1 \%$ of surface irradiance level), except in late spring 2008 when diffuse attenuation coefficients were derived by dividing 1.7 by Secchi Disc depth. Theoretical depths of the 5 simulated in situ light levels were also calculated using the Lambert-Beer law for vertical integration (Parsons et al. 1984). The net primary production rate, measured at each light level, was integrated vertically over the euphotic depth using a trapezoidal method. One potential problem with the integration method is the underestimation of primary production because the 5 light levels were distributed under $<50 \%$ of surface irradiance. However, the theoretical depths of the 5 light levels were uniformly distributed over the euphotic zone because surface irradiance decreased most rapidly at high light levels ranging from 100 to $40 \%$ of surface irradiance. This was confirmed by the underwater light measurements in all seasons. GPP at each station was determined by adding $R_{\text {comm }}$ in the euphotic zone to net primary production assuming constant daily respiration (Hopkinson et al. 1989). The validity of this assumption was confirmed by carrying out 8 experiments at the freshwater end-member, ETM surface, ETM bottom, and seawater end-member at different temperatures ranging from 7 to $23^{\circ} \mathrm{C}$. A set of three $60 \mathrm{ml}$ BOD bottles were sampled every $6 \mathrm{~h}$ during $24 \mathrm{~h}$ incubation, and the regression slopes for ETM stations resulted in an average of $r^{2}=0.92(p<0.001)$, while $r^{2}=0.97(p<$ 0.001) for all other areas.

\section{Respiration measurements}

$R_{\text {comm }}$ and respiration of plankton filtered through a $3 \mu \mathrm{m}$ polycarbonate membrane filter $\left(R_{<3 \mu \mathrm{m}}\right)$ were measured on surface, middle, and bottom water samples as decreases in oxygen concentration in dark BOD bottles for a period of either $12 \mathrm{~h}$ in late winter or $6 \mathrm{~h}$ in spring. The filtration for $R_{<3 \mu \mathrm{m}}$ was done using a reverse gravity method (Crump et al. 1998). Volumetric respiration rates were calculated as the difference in the means between initial and final oxygen concentrations. Respiration rates at the 3 depths were multiplied by the depth of each region, and then summed over the water column to get the total water column rate.

\section{Size-fractionated respiration measurements}

We performed size-fractionated respiration rate measurements to determine the quantitative significance of different size classes in $R_{\text {comm }}$ along with size-fractionated chl a measurements. Standard forward filtration was used in 2007 by gently pouring water through a sequence of filters. Water samples were screened through 20,10, and $3 \mu \mathrm{m}$ Nitex mesh and collected in stirrer-equipped buckets. The $<3 \mu \mathrm{m}$ filtration may include the oxygen demand of bacteria, cyanobacteria, and other small heterotrophs and autotrophs, which are mostly composed of prokaryotes. The $<10$ and $>3 \mu \mathrm{m}$ filtration may include the respiration of heterotrophic flagellates, ciliates, particle-attached bacteria, phytoplankton, and microprotozoa (Hopkinson et al. 1989). The <20 $\mu \mathrm{m}$ filtration would exclude the respiration by macrozooplankton, mesozooplankton, large ciliates, protozoa, and large phytoplankton. Incubation methods were the same as for the normal respiration rate measurements. The size-fractionated measurements can be biased by filtration artifacts (e.g. breaking particles, disturbing organisms, or decreasing predation), resulting, for example, in increased total respiration in filtered samples compared to whole water. This problem sometimes occurred when water was filtered through a $63 \mu \mathrm{m}$ screen, but it did not happen with the smaller filter sizes.

\section{Bacterial production measurements}

Bacterial production in whole water and in water filtered through a $3 \mu \mathrm{m}$ polycarbonate membrane filter $\left(\mathrm{BP}_{<3 \mu \mathrm{m}}\right)$ was measured on surface, middle, and bottom water samples using the incorporation rate of ${ }^{3} \mathrm{H}$-leucine into macromolecules during $1 \mathrm{~h}$ incubations (Kirchman 1993). $\mathrm{BP}_{>3 \mu \mathrm{m}}$, which is referred to here as the production of bacteria in $>3 \mu \mathrm{m}$ water samples, was calculated by subtracting $\mathrm{BP}_{<3 \mu m}$ from BP. The ${ }^{3} \mathrm{H}$-leucine incorporation rate was converted into the production rate assuming a ratio of cellular 
carbon to protein of 0.86 , a fraction of leucine in protein of 0.073 , and an intracellular leucine isotope dilution of 2 (Crump et al. 2007). To compare the relative magnitude of organic matter production by bacteria and autotrophs, a photosynthetic quotient of 1.2 (Smith \& Kemp 1995) was assumed to convert to comparable carbon units. Note that GPP was integrated over the euphotic depth, whereas BP was integrated over the water column.

Total bacterial respiration (BR) could not be measured directly because it is not possible to physically separate eukaryotes from particle-attached bacteria. Therefore, the portion of BR accomplished by $>3 \mu \mathrm{m}$ bacteria $\left(\mathrm{BR}_{>3 \mu \mathrm{m}}\right)$ was estimated using $\mathrm{BP}_{>3 \mu \mathrm{m}}$ and the linear regression relationship between $\mathrm{BP}_{<3 \mu \mathrm{m}}$ and $R_{<3 \mu \mathrm{m}}$. This approach assumes that $<3 \mu \mathrm{m}$ bacteria share the same conversion factor with $>3 \mu \mathrm{m}$ bacteria (Iriberri et al. 1990). BR was then calculated by adding measurements of $R_{<3 \mu \mathrm{m}}$ and estimates of $\mathrm{BR}_{>3 \mu \mathrm{m}}$. Percentages of total $\mathrm{BP}$ and BR, derived from the calculation above, were used to calculate bacterial growth efficiency (BGE).

\section{Phytoplankton pigment analyses}

Pigment samples for high-performance liquid chromatography (HPLC) and fluorometric analysis were collected in duplicate at surface, middle, and bottom depths by filtering water under low light conditions through $25 \mathrm{~mm}$ GF/F filters. The filters were stored at $-80^{\circ} \mathrm{C}$ for $\mathrm{HPLC}$ and $-20^{\circ} \mathrm{C}$ for fluorometric analysis using a low temperature freezer. Upon return to shore, HPLC pigment analysis was performed by Horn Point Laboratory analytical services using methods described in Van Heukelem \& Thomas (2001). In addition, chl $a$ and pheophytin a were measured by extracting the pigments in $90 \%$ acetone and then determined using a fluorometer (Arar \& Collins 1997). The following pigments (and their associated phytoplankton groups or degradation sources) were used in the statistical analyses in the present study: chl $a$, peridinin (dinoflagellates), fucoxanthin (diatoms), alloxanthin (cryptophytes), zeaxanthin (cyanobacteria), and degraded pigments chlorophyllide $a_{\text {, }}$

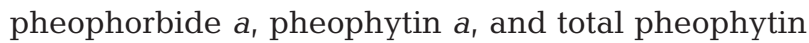
(the sum of degraded pigments).

\section{Statistical analyses}

Due to significant correlations between salinity and phytoplankton pigments, which is common in estuar- ies (Brand 1984), partial correlation analysis was used keeping the salinity effect constant using SAS (SAS Institute). This allows interpretation of correlations among biological variables without the potentially confounding influence of common correlations with salinity. Data point outliers were excluded based on Cook's D-test statistic (Chatterjee \& Hadi 2006). The points excluded from data reported here include 1 $R_{\text {comm }}$ and $2 R_{<3 \mu m}$ rates measured in early spring 2007 that were an order of magnitude higher than the mean respiration rate on the same axial survey. Tests for equal variance and normality were checked with Anderson-Darling and Bartlett's tests, respectively, with a significance level of 0.01 . Due to seasonal differences in environmental conditions, regression statistics for phytoplankton pigments with community metabolism were performed by season.

\section{RESULTS}

The average river discharge in $2007\left(1198 \mathrm{~m}^{3} \mathrm{~s}^{-1}\right)$ was lower than in $2008\left(1871 \mathrm{~m}^{3} \mathrm{~s}^{-1}\right)$ during latewinter cruises (Fig. 2). For 2 wk prior to the cruise in 2007, the mean of water temperature was $0.1^{\circ} \mathrm{C}$ and it resulted in the formation of surface ice covering 3 quarters of upper Chesapeake Bay. As a result, weaker salinity gradients and more well-mixed water columns were observed in 2007, and the interface where the 1 psu isohaline meets the bottom was located further north near $0 \mathrm{~km}$ in 2007 (Fig. 3). Although the turbidity was the lowest among the studied seasons in late winter, the ETMs were observed between 15 and $25 \mathrm{~km}$ in the bottom water. Prior to the early-spring cruises, daily river discharges reached $>6000 \mathrm{~m}^{3} \mathrm{~s}^{-1}$ in 2007 and $>8000 \mathrm{~m}^{3}$ $\mathrm{s}^{-1}$ in 2008 ; this resulted in strong water-column stratification and a more pronounced ETM, leading to the highest turbidity between 25 and $40 \mathrm{~km}$. Although river discharge was higher in 2008 than in 2007,

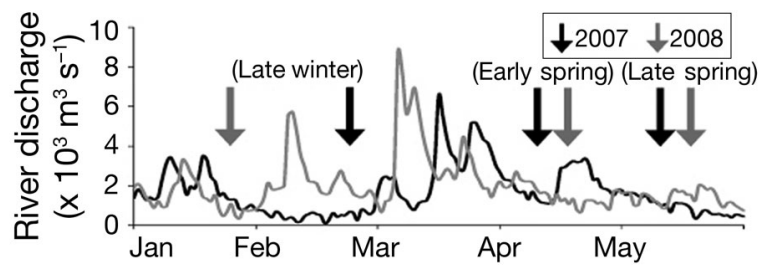

Fig. 2. Daily Susquehanna River discharge at Conowingo Dam in 2007 and 2008 was obtained from the United States Geological Survey (USGS 01578310 station). Arrows indicate the timing of cruises 


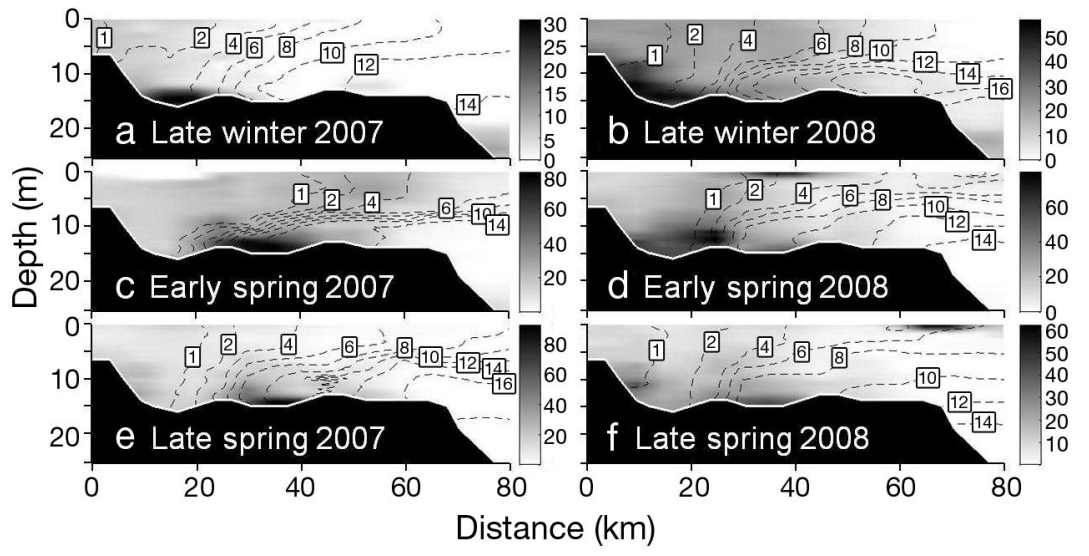

Fig. 3. Contour plots of salinity (dashed lines; unit: psu) and turbidity (shading; in nephelometer turbidity units) measured during 11 CTD casts in (a,b) late winter, (c,d) early spring, and (e,f) late spring in 2007 and 2008. The $x$-axis of each plot presents distances from Turkey Point lighthouse $(0 \mathrm{~km})$ to the Chesapeake Bay Bridge $(80 \mathrm{~km})$ along a shipping channel contributed to the increases in chl a from 45 to $80 \mathrm{~km}$, whereas freshwater diatoms were mainly responsible for the increases in chl a from 0 to $30 \mathrm{~km}$ in early spring (Fig. 4). The dinoflagellate community in the high chl a regions toward the south was dominated by Heterocapsa rotundatum (also known as Katodinium rotundatum) and Prorocentrum minimum. These are mixotrophic (autotrophic and phagotrophic) organisms that are all capable of grazing on bacteria and cryptophytes of various sizes and shapes (Jeong et al. 2005). We observed subsurface maximum concentrations of mixotrophic dinoflagellates throughout the pycnocline from 40 to $80 \mathrm{~km}$.

water-column stratification and turbidity were stronger in 2007. The difference may have been caused by tidal effects, because the timing of the axial survey was from falling ebb to full flood in 2007, whereas the timing was from falling flood to full ebb flows in 2008. Also, in 2007 sharp salinity gradients and strong horizontal pycnoclines were observed from 20 to $80 \mathrm{~km}$ and those were located between 5 and $10 \mathrm{~m}$ depth. In both years the $1 \mathrm{psu}$ isohaline was located down-bay near $20 \mathrm{~km}$, which was further south than in the late winter. In contrast, the mean river discharge dropped to $<1400 \mathrm{~m}^{3} \mathrm{~s}^{-1}$ during the late-spring cruises, resulting in a weaker salinity gradient. This likely also caused the turbid area to manifest in a broad region from 30 to $50 \mathrm{~km}$. Euphotic depths ranged from 1.7 to $3.8 \mathrm{~m}$ in late winter, 1.6 to $3.8 \mathrm{~m}$ in early spring, and 1.5 to $4.4 \mathrm{~m}$ in late spring, and they generally deepened towards the south. Also, on average, $<15 \%$ of the water column was represented by the euphotic zone in all seasons.

\section{Phytoplankton community composition}

Previous studies have revealed that there are diverse phytoplankton communities that co-exist in the upper Chesapeake Bay (Adolf et al. 2006), presumably due to the convergence of salt and fresh water. We observed dinoflagellates, diatoms, and cryptophytes varying in time and space. In general, the phytoplankton communities in the study area were dominated by dinoflagellates and diatoms in terms of their biomass, with substantial spatial and temporal variations. It appears that dinoflagellates and diatoms
The diatom community was mainly composed of small centric species $(<10 \mu \mathrm{m})$, but the biomass of diatoms was more patchy and less abundant than dinoflagellates. Comparably lower concentrations

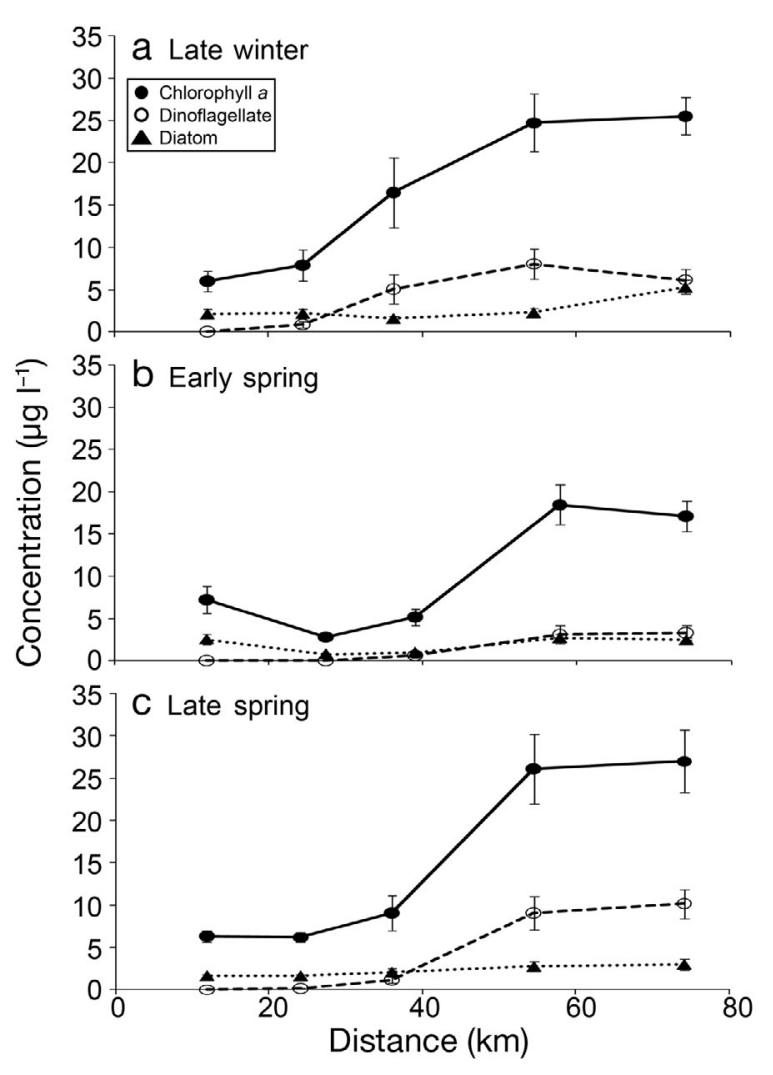

Fig. 4. The 2 yr means of depth-averaged chlorophyll $a$, dinoflagellate (peridinin), and diatom (fucoxanthin) concentrations in (a) late winter, (b) early spring, and (c) late spring for 2007 and 2008. Error bars: 1 SEM ( $n=4$ per season) 


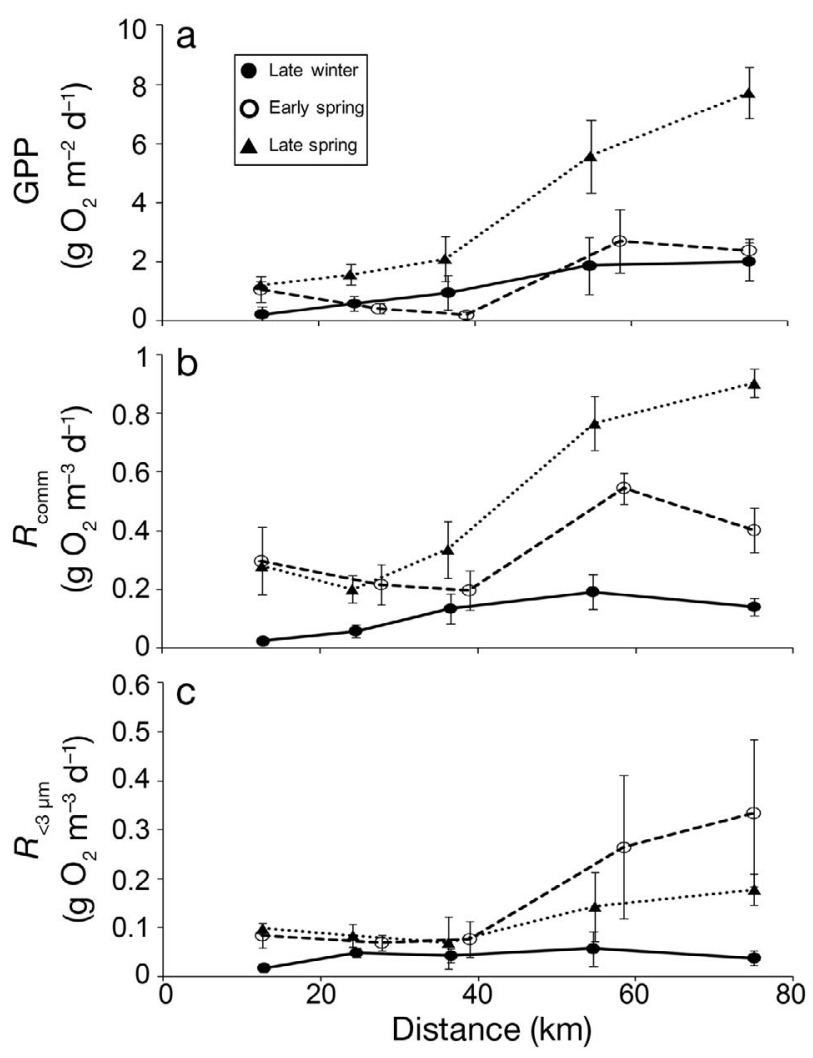

Fig. 5. The 2 yr means of (a) gross primary production (GPP), (b) community respiration $\left(R_{\text {comm }}\right)$, and (c) respiration filtered through $3 \mu \mathrm{m}$ Nitex mesh $\left(R_{<3 \mu \mathrm{m}}\right)$ along the mainstem of Chesapeake Bay in different seasons for 2007 and 2008. In order to account for the 5-fold difference in the water column depth between the seawater end-member and freshwater end-member, vertically integrated respiration rates $(\mathrm{b}, \mathrm{c})$ were divided by water column depths. Error bars: 1 SEM ( $\mathrm{n}=4$ per season)

of fucoxanthin were observed with less distinct spatial trends (Fig. 4). We also observed low concentrations of cryptophytes and cyanobacteria throughout the upper bay, with the concentrations consistently $<1.2 \mu \mathrm{g} \quad \mathrm{l}^{-1}$ for cryptophytes and $0.1 \mu \mathrm{g} \mathrm{l^{-1 }}$ for cyanobacteria.

Plankton community metabolism increased dramatically to the south and varied seasonally (Fig. 5). The lowest and highest GPP values were found in early spring and late spring, respectively, and GPP values were similar in late winter and early spring. In contrast, $R_{\text {comm }}$ was higher in early spring than in late winter, and this increase in $R_{\text {comm }}$ appeared to be due to an increase in $R_{<3 \mu \mathrm{m}}$ (Fig. 5c). The mean GPP per chl a (i.e. the assimilation number) was not different between stations during the entire study $(\mathrm{p}>0.05)$.

The average NEM at the surface indicated net autotrophy in late winter and late spring, but net

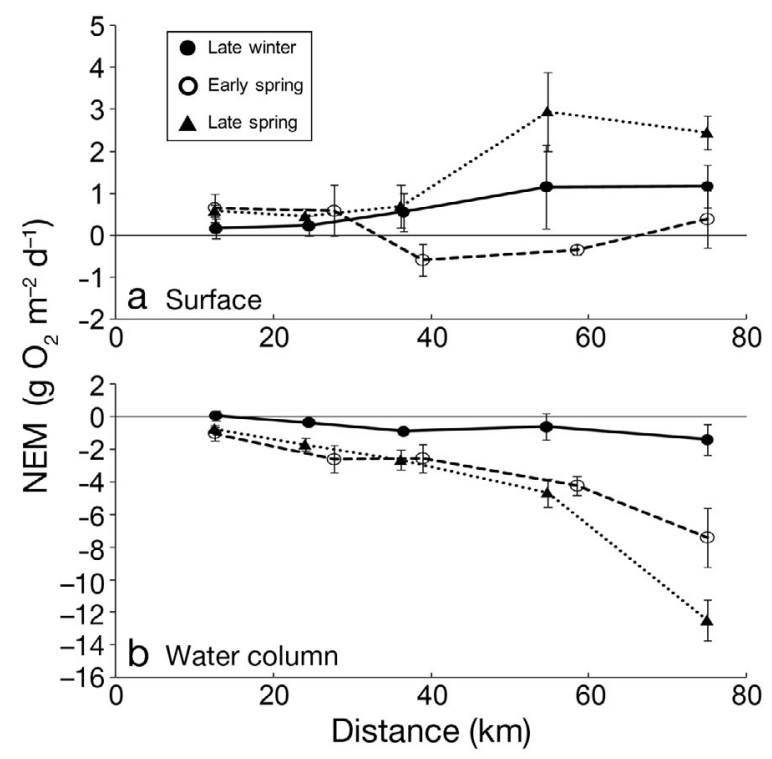

Fig. 6. The 2 yr means of net ecosystem metabolism (NEM) rates (a) near the surface and (b) in the total water column along the mainstem of Chesapeake Bay in different seasons for 2007 and 2008. Error bars: 1 SEM (n = 4 per season)

heterotrophy in the ETM region in early spring (Fig. 6). In contrast, calculations of NEM throughout the water column indicated net heterotrophy, revealing large contributions to respiration from heterotrophs in deeper water below the euphotic zone. Combined production by phytoplankton and bacteria was always greater south of the ETM station due to elevated rates of GPP (Fig. 7). In early spring, the mean contribution by the 2 communities was relatively balanced when averaged across the whole transect, but the contribution from BP was much higher (76\%) than GPP in the ETM. In late spring the contribution of autotrophic carbon was $>65 \%$ at all stations along the transect.

\section{Statistical analysis for gross primary production}

Although correlation coefficients and statistical significance vary by seasons, the results derived using the entire data set captured general patterns and magnitudes of correlations. The analysis revealed that GPP was significantly correlated with several environmental and biological factors (Table 1). However, there were also significant correlations between salinity and most of the phytoplankton pigments (except cyanobacteria), making it difficult to interpret these results due to multicollinearity.

Partial correlation analysis, keeping salinity constant, was therefore employed and resulted in an 


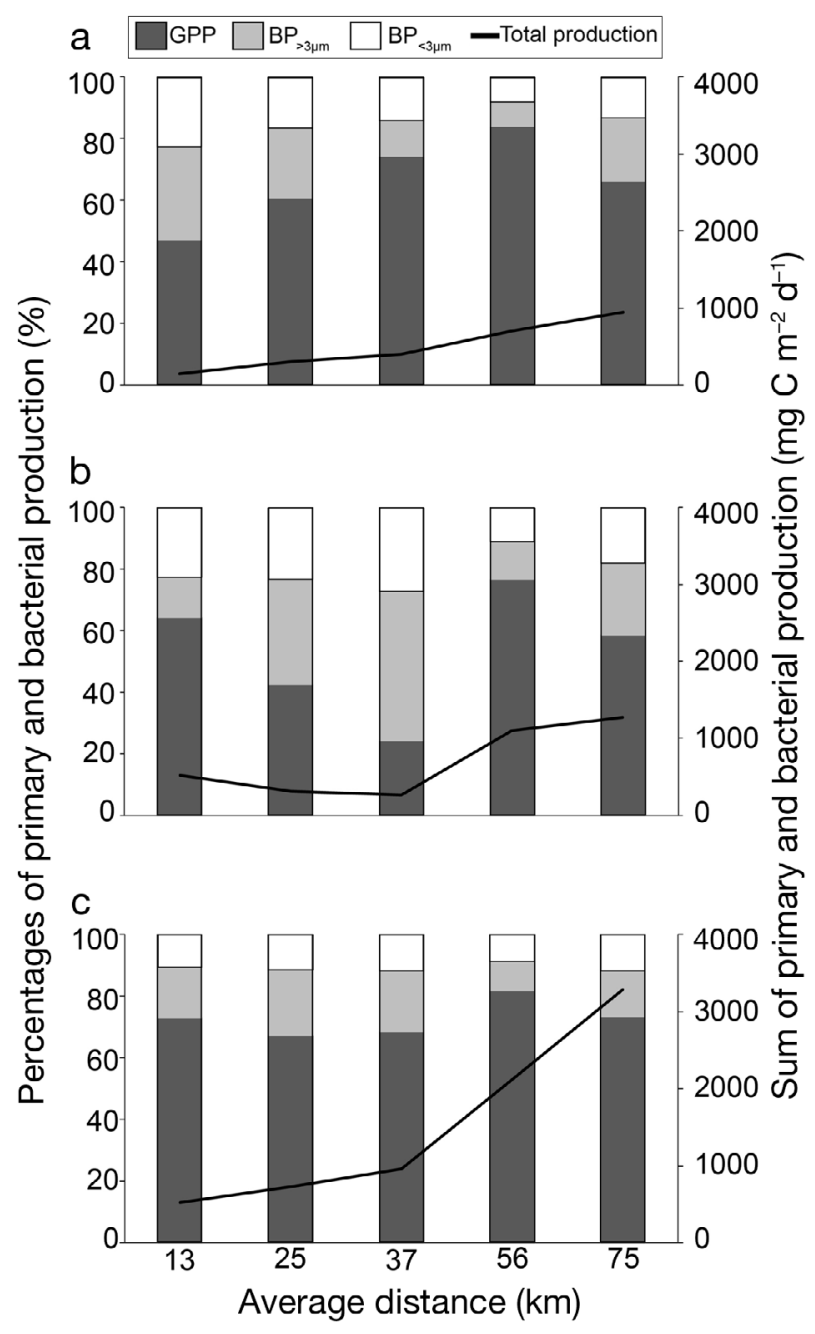

Fig. 7. Percentages of 2 yr carbon production rates produced by phytoplankton (gross primary production, GPP), bacteria $>3 \mu \mathrm{m}\left(\mathrm{BP}_{>3 \mu \mathrm{m}}\right)$, and bacteria $<3 \mu \mathrm{m}\left(\mathrm{BP}_{<3 \mu \mathrm{m}}\right)$ in (a) late winter, (b) early spring, and (c) late spring (left $y$-axis). Lines are the sums of the 3 production rates (right $y$-axis) overall decline in the correlation coefficients for all variables. However, significant relationships were still found with GPP, except with the cryptophyteindicating pigment alloxanthin. Among the pigments, chl $a$, peridinin, fucoxanthin, and zeaxanthin were all significantly correlated with GPP, indicating that changes in total phytoplankton abundance and, specifically, the abundance of individual phytoplankton groups were driving changes in GPP (Table 1). However, the contribution of cyanobacteria to GPP was much lower than dinoflagellates and diatoms because of low concentration. Phytoplankton pigments were also strongly correlated with salinity, suggesting that salinity control/stress can be an important factor in determining the phytoplankton community composition. Among the environmental variables, temperature was the most important factor explaining the variability in GPP, suggesting that there was seasonal thermal kinetic control of phytoplankton production. Total suspended sediment (TSS) was negatively correlated with GPP and euphotic depth was positively correlated with GPP because high TSS concentrations result in lower light availability, which lowers GPP (Xu et al. 2005). It should be noted, however, that TSS and euphotic depth were not correlated with GPP on any of the individual cruises (data not shown), suggesting that seasonal changes in TSS and euphotic depth (rather than spatial changes) were driving these correlations.

Season by season regression analyses revealed that the chl a concentration explained $\geq 72 \%$ ( $p<0.01)$ of the variation of GPP in late winter and late spring (Fig. 8), but only $40 \%(p<0.01)$ of the variation in early spring (graph not shown). Significant fractions of GPP were also explained by dinoflagellate concentrations (Fig. 8). The dinoflagellate pigment explained $\geq 70 \%(\mathrm{p}<0.01)$ of GPP in late winter and late spring,

Table 1. Partial correlation matrix of salinity and environmental and biological variables at the surface with gross primary pro-

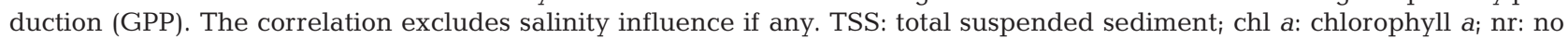
relationship if $\mathrm{r}<0.2 ;{ }^{* *} \mathrm{p}<0.01 ;{ }^{*} 0.01<\mathrm{p}<0.05 ; \mathrm{n}=60$

\begin{tabular}{|c|c|c|c|c|c|c|c|c|c|}
\hline & Salinity & Temp. & TSS & $\begin{array}{l}\text { Euphotic } \\
\text { depth }\end{array}$ & Chl a & $\begin{array}{l}\text { Dino- } \\
\text { flagellate }\end{array}$ & Diatom & $\begin{array}{l}\text { Crypto- } \\
\text { phyte }\end{array}$ & $\begin{array}{c}\text { Cyano- } \\
\text { bacteria }\end{array}$ \\
\hline GPP & $0.46^{* *}$ & $0.58^{* *}$ & $-0.31^{*}$ & $0.32^{*}$ & $0.74^{* *}$ & $0.64^{* *}$ & $0.33^{*}$ & $\mathrm{nr}$ & $0.58^{* *}$ \\
\hline Temperature & -0.24 & & $-0.34^{* *}$ & $0.32^{*}$ & 0.25 & $\mathrm{nr}$ & $\mathrm{nr}$ & 0.21 & $0.35^{* *}$ \\
\hline TSS & -0.21 & & & $-0.61^{* *}$ & $\mathrm{nr}$ & $\mathrm{nr}$ & $-0.33^{*}$ & $\mathrm{nr}$ & $\mathrm{nr}$ \\
\hline Euphotic depth & $0.60^{* *}$ & & & & $\mathrm{nr}$ & $\mathrm{nr}$ & $0.26^{*}$ & 0.23 & $\mathrm{nr}$ \\
\hline Chl a & $0.65^{* *}$ & & & & & $0.83^{* *}$ & $0.39^{* *}$ & $\mathrm{nr}$ & $0.43^{* *}$ \\
\hline Dinoflagellate & $0.57^{* *}$ & & & & & & $\mathrm{nr}$ & $\mathrm{nr}$ & $\mathrm{nr}$ \\
\hline Diatom & $0.34^{* *}$ & & & & & & & $\mathrm{nr}$ & $0.55^{* *}$ \\
\hline Cryptophyte & $0.54^{* *}$ & & & & & & & & $\mathrm{nr}$ \\
\hline Cyanobacteria & $\mathrm{nr}$ & & & & & & & & \\
\hline
\end{tabular}




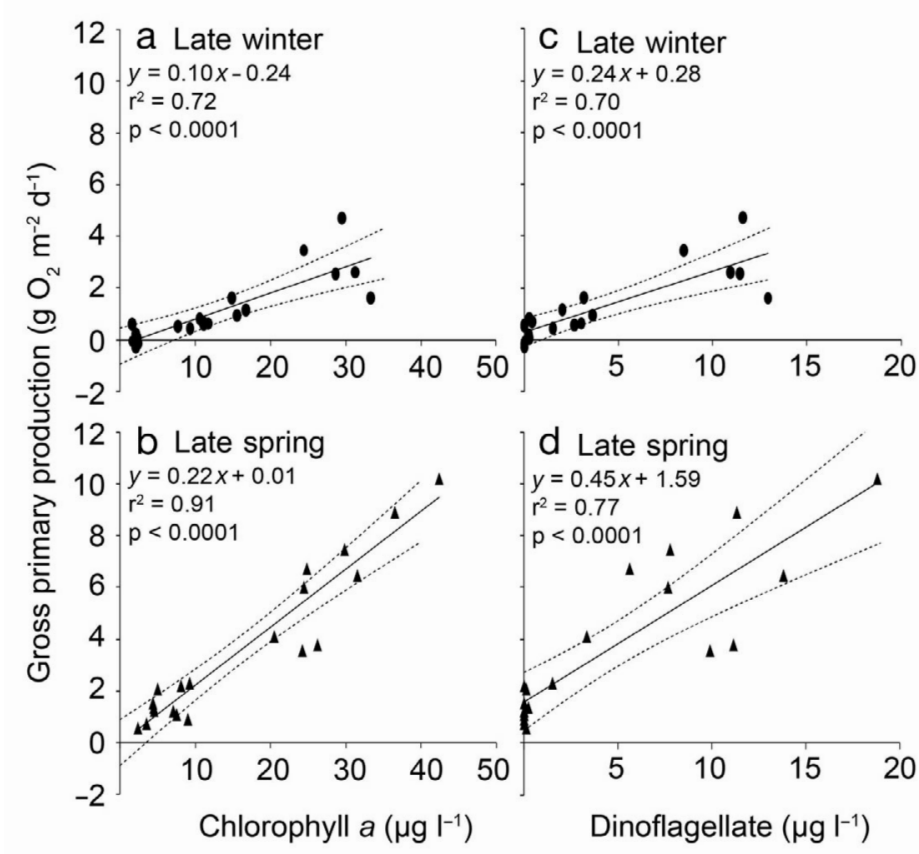

Fig. 8. Regression analysis of gross primary production with the concentrations of $(a, b)$ surface chlorophyll $a$ and $(c, d)$ the dinoflagellate-indicating pigment peridinin in late winter and late spring of 2007 and 2008. The best-fit line is calculated from a least-squares method, and the 2 dotted lines are $95 \%$ prediction bounds; $\mathrm{n}=20$. None of the $y$-intercepts were different from $0(p>0.05)$

but only $3 \%(p=0.45)$ in early spring (graph not shown). Whereas the diatom pigment explained a relatively smaller fraction of the GPP variability: $2 \%(\mathrm{p}=$ $0.59)$ in late winter, $27 \%(p<0.05)$ in early spring, and $40 \%(\mathrm{p}<0.01)$ in late spring. The stronger correlation between GPP and diatom pigment in early spring compared to dinoflagellate pigment was, in part, caused by high diatom concentrations between 0 and $35 \mathrm{~km}$, which corresponded to an increase in GPP in the area (Figs. 4 \& 5).

\section{Statistical analyses for community respiration}

Here also, partial correlation was used due to multicollinearity. Chl $a$, peridinin, pheophytin $a$, and BP were all positively correlated with $R_{\text {comm }}$, while chl $a$ and peridinin were not correlated with $R_{<3 \mu m}$ (Table 2). Positive correlations between TSS and degraded pigments, including pheophorbide $a$, pheophytin $a$, and total pheophytin, suggest that the ETM was a site for deposition of degraded pigments. Among all variables, temperature is considered to be one of the most important influencing the respiration of bacteria (Shiah \& Ducklow 1994), plankton (Sampou \& Kemp 1994), and the entire estuarine community (Caffrey 2004). It is therefore not surprising that a significant correlation was found between temperature and both $R_{\text {comm }}$ and $R_{<3 \mu \mathrm{m}}$. However, temperature was not significantly correlated with respiration on any of the individual cruises (data not shown), suggesting that seasonal changes in temperature (rather than spatial changes) were driving these correlations. More interestingly, TSS was inversely correlated with $R_{\text {comm }}$ in early spring ( $\mathrm{r}=-0.34$, $\left.\mathrm{p}<0.01\right)$, late spring $(\mathrm{r}=-0.50, \mathrm{p}<0.01)$, and for the entire data set (Table 2).

Variations in chl a explained $\geq 62 \%(p<0.01)$ of the variations in $R_{\text {comm }}$ in late winter and late spring (Fig. 9), but only $32 \%(\mathrm{p}<0.01)$ in early spring (graph not shown). Also, $\geq 62 \%$ ( $<<0.01$ ) of the variability in $R_{\text {comm }}$ was explained by the dinoflagellate pigment in late winter and late spring, but only $5 \%(p=0.08)$ in early spring (graph not shown). These results suggest that variations in the dinoflagellate populations played a very large role in driving $R_{\text {comm }}$ during late winter and late spring. The significant correlation

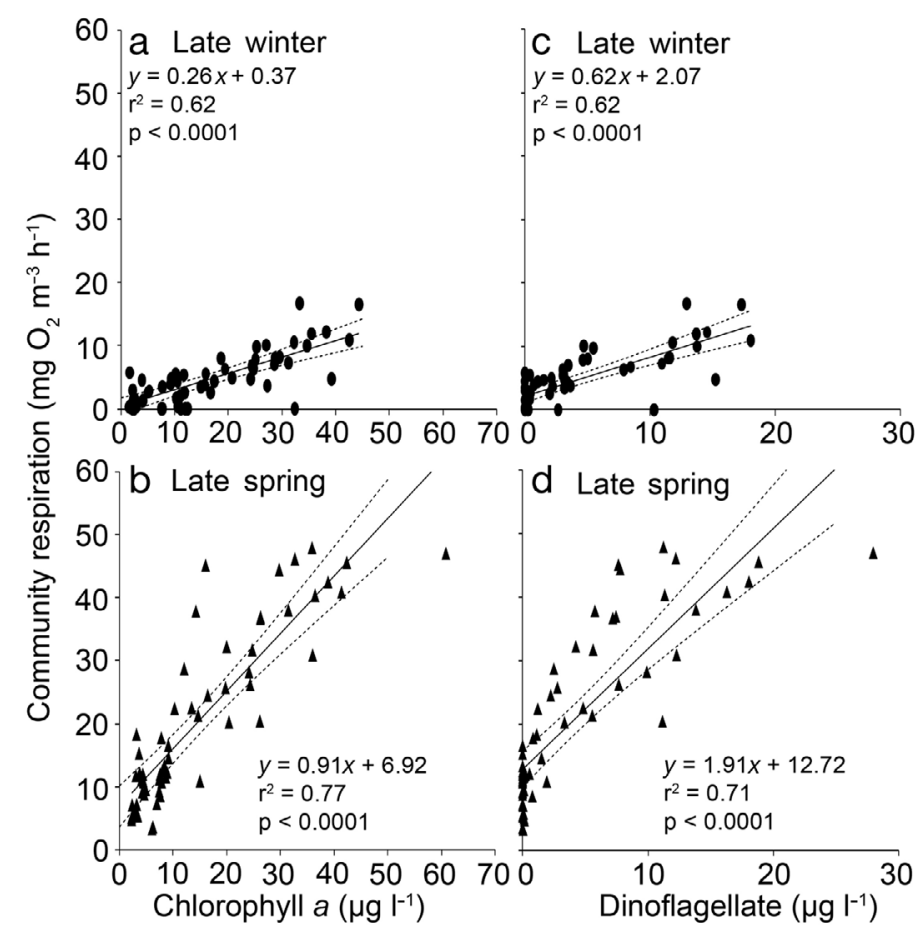

Fig. 9. Regression analysis of community respiration and the concentrations of $(\mathrm{a}, \mathrm{b})$ chlorophyll $a$ and $(\mathrm{c}, \mathrm{d})$ the dinoflagellate-indicating pigment peridinin in late winter and late spring of 2007 and 2008. The best-fit line is calculated from a least-squares method, and the 2 dotted lines are $95 \%$ prediction bounds; $\mathrm{n}=60$. The $y$-intercepts were significantly different from $0(\mathrm{p}<0.01)$ in late spring $(\mathrm{b}, \mathrm{d})$ 
Table 2. Partial correlation matrix of salinity and environmental and biological variables for the total water column with respiration. $R_{\text {comm }}$ : community respiration; $R_{<3 \mu \mathrm{m}}$ : respiration of plankton filtered through a $3 \mu$ polycarbonate membrane filter; TSS: total suspended sediment; chl $a$ : chlorophyll $a_{i} \mathrm{BP}$ : total bacterial production; $\mathrm{BP}_{<3 u m}$ : production of bacteria filtered through a $3 \mu \mathrm{m}$ polycarbonate membrane filter; nr: no relationship if $\mathrm{r}<0.2{ }^{*}{ }^{* *} \mathrm{p}<0.01 ;{ }^{*} 0.01<\mathrm{p}<0.05 ; \mathrm{n}=180$, but $\mathrm{n}=165$ for the 2 bacterial production values

\begin{tabular}{|c|c|c|c|c|c|c|c|c|c|}
\hline & Salinity & $R_{<3 \mu \mathrm{m}}$ & \multicolumn{2}{|c|}{ Temperature } & TSS & Chl a & Dinoflagellate & Diatom & Cryptophyte \\
\hline$R_{\text {comm }}$ & $0.34^{* *}$ & \multirow[t]{15}{*}{$0.56^{* *}$} & \multirow{2}{*}{\multicolumn{2}{|c|}{$\begin{array}{l}0.58^{* *} \\
0.39^{* *}\end{array}$}} & $-0.28^{* *}$ & $0.46^{* *}$ & $0.43^{* *}$ & $\mathrm{nr}$ & $\mathrm{nr}$ \\
\hline$R_{<3 \mu \mathrm{m}}$ & $\mathrm{nr}$ & & & & $\mathrm{nr}$ & $\mathrm{nr}$ & $\mathrm{nr}$ & $\mathrm{nr}$ & $\mathrm{nr}$ \\
\hline Temperature & $\mathrm{nr}$ & & & & $\mathrm{nr}$ & $\mathrm{nr}$ & $\mathrm{nr}$ & $\mathrm{nr}$ & $\mathrm{nr}$ \\
\hline TSS & $\mathrm{nr}$ & & & & & $\mathrm{nr}$ & $\mathrm{nr}$ & $\mathrm{nr}$ & $\mathrm{nr}$ \\
\hline Chl a & $0.53^{* *}$ & & & & & & $0.90^{* *}$ & $0.30^{* *}$ & $0.38^{* *}$ \\
\hline Dinoflagellate & $0.42^{* *}$ & & & & & & & $\mathrm{nr}$ & $0.25^{* *}$ \\
\hline Diatom & $0.44^{* *}$ & & & & & & & & $\mathrm{nr}$ \\
\hline Cryptophyte & $0.43^{* *}$ & & & & & & & & \\
\hline Cyanobacteria & $\mathrm{nr}$ & & & & & & & & \\
\hline Chlorophyllide a & $0.47^{* *}$ & & & & & & & & \\
\hline Pheophorbide a & $0.69^{* *}$ & & & & & & & & \\
\hline Pheophytin a & $0.48^{* *}$ & & & & & & & & \\
\hline Total pheophytin & $0.34^{* *}$ & & & & & & & & \\
\hline $\mathrm{BP}$ & $\mathrm{nr}$ & & & & & & & & \\
\hline \multirow[t]{2}{*}{$\mathrm{BP}_{<3 \mu \mathrm{m}}$} & $\mathrm{nr}$ & & & & & & & & \\
\hline & $\begin{array}{l}\text { Cyano- } \\
\text { bacteria }\end{array}$ & $\begin{array}{r}\mathrm{Cl} \\
\text { phy }\end{array}$ & $\begin{array}{l}\text { oro- } \\
\text { lide } a\end{array}$ & $\begin{array}{r}\text { Ph } \\
\text { phork }\end{array}$ & $\begin{array}{l}\text { o- } \\
\text { de } a\end{array}$ & $\begin{array}{l}\text { Pheo- } \\
\text { phytin a }\end{array}$ & $\begin{array}{c}\text { Total } \\
\text { pheophytin }\end{array}$ & $\mathrm{BP}$ & $\mathrm{BP}_{<3 \mu \mathrm{m}}$ \\
\hline$R_{\text {comm }}$ & $\mathrm{nr}$ & & $23^{* *}$ & $\mathrm{n}$ & & $0.33^{* *}$ & $\mathrm{nr}$ & $0.44^{* *}$ & $0.60^{* *}$ \\
\hline$R_{<3 \mu \mathrm{m}}$ & $0.30^{* *}$ & & $27^{* *}$ & $\mathrm{n}$ & & $0.29^{* *}$ & $\mathrm{nr}$ & $0.27^{* *}$ & $0.47^{* *}$ \\
\hline Temperature & $\mathrm{nr}$ & & $22^{* *}$ & $\mathrm{n}$ & & $0.36^{* *}$ & $\mathrm{nr}$ & $0.37^{* *}$ & $0.49^{* *}$ \\
\hline TSS & $0.59^{* *}$ & & $\mathrm{hr}$ & & $3^{* *}$ & $0.47^{* *}$ & $0.70^{* *}$ & $\mathrm{nr}$ & $-0.23^{* *}$ \\
\hline Chl a & $\mathrm{nr}$ & & $39^{* *}$ & $\mathrm{n}$ & & $\mathrm{nr}$ & $-0.23^{* *}$ & $\mathrm{nr}$ & $\mathrm{nr}$ \\
\hline Dinoflagellate & $\mathrm{nr}$ & & $31^{* *}$ & -0.2 & $4^{* *}$ & $\mathrm{nr}$ & $-0.28^{* *}$ & $\mathrm{nr}$ & $\mathrm{nr}$ \\
\hline Diatom & $0.32^{* *}$ & & $35^{* *}$ & & )$^{* *}$ & $0.26^{* *}$ & $\mathrm{nr}$ & $\mathrm{nr}$ & $0.32^{* *}$ \\
\hline Cryptophyte & $\mathrm{nr}$ & & $25^{* *}$ & $\mathrm{n}$ & & $\mathrm{nr}$ & $\mathrm{nr}$ & $\mathrm{nr}$ & $\mathrm{nr}$ \\
\hline Cyanobacteria & & & $\mathrm{ar}$ & & $j^{* *}$ & $0.67^{* *}$ & $0.59^{* *}$ & $\mathrm{nr}$ & $0.21^{* *}$ \\
\hline Chlorophyllide a & & & & $\mathrm{n}$ & & $-0.21^{* *}$ & $\mathrm{nr}$ & $\mathrm{nr}$ & $\mathrm{nr}$ \\
\hline Pheophorbide a & & & & & & $0.62^{* *}$ & $0.73^{* *}$ & $\mathrm{nr}$ & $\mathrm{nr}$ \\
\hline Pheophytin a & & & & & & & $0.60^{* *}$ & $0.37^{* *}$ & $0.47^{* *}$ \\
\hline Total pheophytin & & & & & & & & $\mathrm{nr}$ & $\mathrm{nr}$ \\
\hline $\mathrm{BP}$ & & & & & & & & & $0.62^{* *}$ \\
\hline
\end{tabular}

between dinoflagellates and cryptophytes also reveals a spatial co-occurrence between the 2 communities which may be indicative of a prey-predator relationship.

Size-fractionated respiration varied in time and space, and $R_{<3 \mu \mathrm{m}}$ did not dominate $R_{\text {comm }}$. This is in contrast to the results of Smith \& Kemp (2001) who found that bacteria in $<3 \mu \mathrm{m}$ samples contributed $>50 \%$ of the respiration in the mesohaline and polyhaline regions of Chesapeake Bay. Chl a concentrations in $<3 \mu \mathrm{m}$ samples were usually $<1 \mu \mathrm{g} \mathrm{l}^{-1}$, which is $<10 \%$ of total chl $a$, at all sampling stations. Statistically significant differences in respiration rate were not found in different size fractions at the freshwater end-member, where approximately $80 \%$ of chl a consisted of $>20 \mu \mathrm{m}$ phytoplankton communities (graphs not shown). The measurements carried out on ETM surface water were highly variable (graphs not shown). However, consistent results were obtained from measurements of ETM bottom water and the seawater end-member samples (Fig. 10). These results indicate that approximately $85 \%$ of $R_{\text {comm }}$ was performed by organisms of size $3-10 \mu \mathrm{m}$ in the early and late spring, when 61 and $74 \%$ of chl a was found in the size range, respectively.

Linear regression analysis between $\mathrm{BP}_{<3 \mu \mathrm{m}}$ and $R_{<3 \mu \mathrm{m}}$ resulted in $\mathrm{r}^{2}=0.53(\mathrm{p}<0.001)$ in early spring and $\mathrm{r}^{2}=0.74(\mathrm{p}<0.001)$ in late spring, but it was not correlated in late winter $\left(r^{2}=0.06, p>0.05\right)$. The estimated total BR indicated that the contribution of total bacteria to average $R_{\text {comm }}$ was $61 \%$ in early spring and $38 \%$ in late spring. In addition, BGE was estimated to be 0.18 in early spring and 0.19 in late spring. 


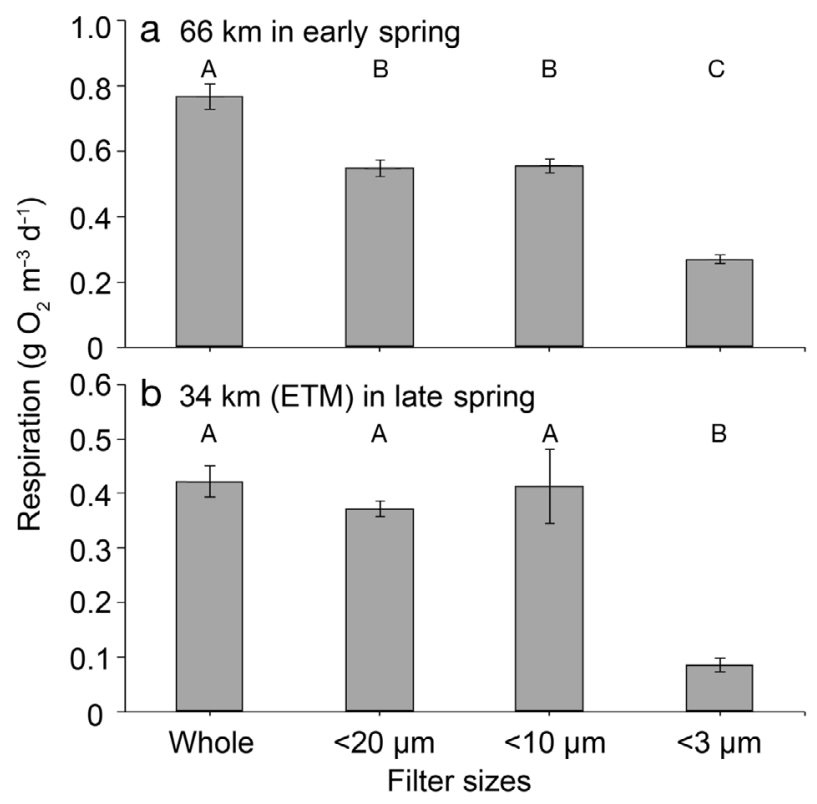

Fig. 10. Size-fractionated respiration rates at (a) $66 \mathrm{~km}$ in early spring and (b) $34 \mathrm{~km}$, where the estuarine turbidity maximum (ETM) was observed, in late spring in 2007. Tukey's Studentized range test was used to investigate statistical differences between groups. Different letters indicate significant differences $(\mathrm{p}<0.05)$. Error bars equal estimates of the propagated standard error for a set of triplicate samples

\section{DISCUSSION}

The purpose of the present study was to estimate plankton community metabolism and investigate the fundamental structure of the estuarine food web in the Chesapeake Bay ETM region in relation to environmental and biological influences during the winter to spring period. We consistently observed higher and more variable metabolic rates seaward of the ETM region between 45 and $80 \mathrm{~km}$ compared to between 0 and $45 \mathrm{~km}$, which encompasses the freshwater end-member and ETM region. These elevated rates were associated with higher pigment concentrations. Most of these metabolism results are comparable to previous studies in the upper Chesapeake Bay, although the mean GPP in late spring was about 2-fold higher than that observed in previous work in the upper bay (Smith \& Kemp 1995, 2003). This discrepancy was likely caused by differences in the defined seawater end-member stations between studies and/or temporal variability in GPP.

The NEM results are dependent upon where we draw the boundaries of our domain, because they are derived from knowledge of the spatial and temporal scales of hydrologic forcing and biological function- ing. We used 2 domains (surface and water column) because the former provides insight into the short and narrow scale of the food web in the surface layer but the latter provides insight into the longer and broader scale of the food web controlled by estuarine circulation (Fig. 6). The NEM results suggest that in situ primary production supplied more organic matter than was consumed in the surface layer in late winter and late spring. However, higher river discharge in early spring increased the input of allochthonous organic matter relative to other seasons and resulted in net heterotrophy in the surface between 40 and $60 \mathrm{~km}$. Water column NEM resulted in strong net heterotrophy due to respiration throughout the water column. Net increases in dissolved organic carbon have been reported in the ETM (Fisher et al. 1998), which can be caused by zooplankton and bacterial activity and also phytoplankton cell lysis associated with salinity changes. The heterotrophic activity may also result in increasing organic aggregate sizes (Simon et al. 2002) and settling velocities of ETM particles (Sanford et al. 2001). Below the pycnocline, organic matter may have originated from overlying waters, lateral shallow areas, and advective transport from down-bay (Malone et al. 1986). Thus, net heterotrophy in the water column, especially bottom respiration, more likely resulted from diverse sources of allochthonous organic matter.

\section{Environmental factors controlling primary production}

Near-surface assimilation numbers did not drop significantly in the ETM region on any of the cruises, suggesting that the phytoplankton there were not compromised physiologically by low light levels. Also, increases in euphotic depth in the south were not correlated with GPP on any of the individual cruises, suggesting that light is not the most important factor controlling variations in primary production in the ETM region. These results are in contrast to the findings of previous studies of the Chesapeake Bay (Harding et al. 1986, Fisher et al. 1999) and other estuaries (Cloern et al. 1983, Irigoien \& Castel 1997), which have pointed to light limitation as the most likely factor driving variations in GPP in the ETM region. This would, however, likely be true if GPP were compared to euphotic depth throughout the entire bay due to significantly shallower euphotic depths in the oligohaline compared to the meso- and polyhaline regions (see Fig. 2 in Smith \& Kemp 1995). 
Year-to-year variations in water properties and the distribution of phytoplankton are tightly coupled to the variation of the Susquehanna River discharge (Harding 1994), suggesting that there are direct influences of physical mechanisms on the concentration of phytoplankton in the bay. Peaks in river flow during the spring freshet generated strong salinity gradients and, presumably, strong gravitational circulation, which increases the seaward and landward flow. Light limitation, mentioned above, is the result of the indirect effect of the river flow, but this does not appear to be important in determining GPP variations within the ETM region. In contrast, the transport of phytoplankton communities by surface and bottom water flow appears to cause the inflow of freshwater diatoms from the Susquehanna River and predominantly dinoflagellates from the southern part of the upper bay to the ETM region (Fig. 4). Thus, the latitudinal gradient of phytoplankton biomass, influenced by the hydrological process, appears to be the most important factor determining the variation of GPP in the ETM region. As in the upper Neuse River estuary, where hydrologic forcing controls phytoplankton dynamics (Arhonditsis et al. 2007), the hydrological processes that effect the distribution of phytoplankton, and thus GPP, must be significant in this region, since along-channel current velocities can reach $>60 \mathrm{~cm} \mathrm{~s}^{-1}$ near the ETM during a typical tidal cycle (Sanford et al. 2001) and a river flow of 3000 to $4000 \mathrm{~m}^{3} \mathrm{~s}^{-1}$ can produce a mean seaward velocity of 12 to $15 \mathrm{~cm} \mathrm{~s}^{-1}$ above the ETM (Park et al. 2008). Furthermore, seaward of the ETM, where the water column is stratified and 2-layer circulation prevails, the tidally averaged along-channel residual current velocities in each layer are around $10 \mathrm{~cm} \mathrm{~s}^{-1}$ and background vertical mixing is on the order of $10^{-6} \mathrm{~m}^{2} \mathrm{~s}^{-1}$ ( $\mathrm{Li}$ et al. 2005). Phytoplankton, like any suspended particle, are subjected to these hydrodynamic forces and moved throughout the upper bay as a result.

One 3-dimensional modeling study that examined the transport and sedimentation of TSS (Park et al. 2008) showed that the 15 d average seaward horizontal flux of TSS in the surface layer ranged between $1.6 \times 10^{-4}$ and $5.0 \times 10^{-4} \mathrm{~kg} \mathrm{~m}^{-2} \mathrm{~s}^{-1}$ when river discharge was low-to-moderate and between $18.8 \times 10^{-4}$ and $46.8 \times 10^{-4} \mathrm{~kg} \mathrm{~m}^{-2} \mathrm{~s}^{-1}$ when river discharge was high. Conversely, the landward horizontal flux of TSS in the bottom layer ranged between $6.2 \times 10^{-4}$ and $15.3 \times 10^{-4} \mathrm{~kg} \mathrm{~m}^{-2} \mathrm{~s}^{-1}$ when river discharge was low-to-moderate and between $12.3 \times 10^{-4}$ and $21.8 \times$ $10^{-4} \mathrm{~kg} \mathrm{~m}^{-2} \mathrm{~s}^{-1}$ when river discharge was high. If we assume that phytoplankton behave in a similar manner as do suspended sediments, although likely with less sinking, then the model results by Park et al. (2008) suggest that substantial transport occurs. The dynamics of this transport will cause freshwater phytoplankton, and others that are in the surface layer to the south, to be transported seaward, while any phytoplankton that are below the pycnocline, as the dinoflagellates often were, will be transported north toward the ETM. During, or as a result of transport, hydrodynamic processes and bio-physical interactions may cause phytoplankton to become trapped in the ETM or to move across a salinity gradient with either processes likely causing mortality or stress. As a result freshwater phytoplankton and those from more saline waters tend to form separate communities, which will have different levels of GPP, on either side of the ETM and areas where the salinity gradient is steep (i.e. these are salinity stress/mortality barriers to phytoplankton that prevent individual species from growing successfully throughout the whole upper bay). Indeed, the stress caused when phytoplankton are trapped in the ETM or cross a salinity gradient may be the primary reason why GPP was low in certain areas, since stressed phytoplankton will not be able to grow as well as healthy ones. Thus, we suggest that the physical transport of phytoplankton and the resulting bio-physical interactions are equally or more important than light limitation for explaining variations in GPP in the ETM region.

\section{Role of dinoflagellates}

Correlation analyses indicate that autochthonous organic matter originating from dinoflagellates was an important source of carbon to the ecosystem in the oligohaline region during the winter to spring period, which may be attributable to the physiological attributes of these organisms. Variations in dinoflagellate pigments alone explained much of the variability in GPP, with the second highest correlation, after chl a (Table 1). Regression analyses for each of the cruises also revealed that dinoflagellates were highly correlated with GPP, except in early spring (Fig. 8).

Dinoflagellates found in Chesapeake Bay are highly adaptable to environmental changes (e.g. salinity, light availability, and nutrients) and many can switch between heterotrophic and autotrophic feeding modes (Stoecker 1998). This adaptability may help to explain the high abundances of dinoflagellates in the bay in winter and spring when environmental conditions rapidly change. These dinoflagellates are often found below the compensation 
depth, and are thought to use various mechanisms to survive under low light conditions during the lengthy transport from the mouth of the bay (Tyler \& Seliger 1978, Wofsy 1983, Cole et al. 1992). Harding (1988) found that dinoflagellates, specifically Prorocentrum minimum, are capable of enhancing the efficiency of light harvest by increasing chl $a$ and peridinin per cell and by increasing the initial slope of the photosynthesis-light curve. More importantly, the phagotrophic capability of mixotrophic dinoflagellates is particularly beneficial because it can provide both carbon and nutrients in low light and low nutrient conditions. This feeding strategy has been found in many dinoflagellate species in diverse environments (Sanders 1991, Stoecker et al. 1997).

\section{Role of diatoms}

The partial correlation results suggest that the contribution of diatoms to GPP was generally less than that of dinoflagellates. Diatom concentrations were generally lower than dinoflagellates, and they were not correlated with GPP on any of the individual cruises, but they were significantly correlated with GPP over the entire data set (Table 1). However, when the salinity effect is not removed (i.e. normal correlation analysis), diatom concentrations significantly explained variations in GPP in early spring $(\mathrm{r}=$ $0.52, \mathrm{p}<0.05)$ and late spring $(\mathrm{r}=0.63, \mathrm{p}<0.01)$. This suggests that diatoms were more sensitive to salinity changes than dinoflagellates and that mortality due to salinity stress strongly affected the fate of diatoms in the oligohaline region.

It should also be noted that this sensitivity might lead to underestimation of the contribution of diatoms to bacterial and microheterotrophic production. Salinity changes are most rapid in the oligohaline, and they can influence the fate of phytoplankton because the optimal salinity ranges of phytoplankton are species specific. Although the estuarine phytoplankton community has a wider salinity tolerance compared to oceanic and coastal species (Brand 1984), it is clear that different phytoplankton communities were responsible for autotrophic production in the different salinity regimes that we sampled, i.e. freshwater diatoms dominated the flora in the freshwater to oligohaline transition and marine/estuarine dinoflagellates dominated the flora in the oligohaline to mesohaline transition (Fig. 4). The transition between these 2 dominant floral groups was abrupt, and it generally happened across the 0 to 1 isohalines in the ETM region. These results suggest that diatom mortality rates were high in this region, likely due to osmotic stress. Similarly, in the Schelde Estuary, freshwater phytoplankton communities showed the weakest ability to adapt to seawater and rapidly disappeared and were replaced by estuarine species when salinity increased to $>0.5$ (Muylaert et al. 2000). Thus, physiological (cellular lysis) and physical (sinking loss) processes may prevent diatoms from growing in the ETM. However, the death of these cells in the ETM may release dissolved organic matter (Fisher et al. 1998), which can be consumed by bacteria and microheterotrophs, thus contributing to secondary production.

In addition, the importance of diatoms might be underestimated by the exclusion of benthic diatoms in the analysis. Benthic diatoms cannot inhabit the deep shipping channel in Chesapeake Bay due to light limitation. This impediment is worsened in the oligohaline due to high concentrations of TSS, which cause rapid light attenuation. However, filamentous algae and chain-forming diatoms observed beneath ice cover on the late-winter cruise in 2007 suggest that, in years with ice, diatoms may contribute organic matter to secondary producers. Ichinomiya et al. (2009) estimated that approximately $50 \%$ of diatoms released from ice are exploited by both pelagic and benthic grazers, while only $3 \%$ of diatom loss is attributable to sinking. Thus, if there was rapid and selective grazing on diatoms by abundant copepods and microzooplankton, a significant fraction of ice-attached diatoms might be consumed by the pelagic grazers. Although surface ice formation in the oligohaline Chesapeake Bay is not an annual event, further study is needed to estimate the contribution of ice-attached diatoms.

\section{Comparison between primary and bacterial production}

GPP in general contributed more organic carbon than $\mathrm{BP}$, although this varied in space and time (Fig. 7). In addition, BP in the ETM was relatively low compared to the region between 45 and $80 \mathrm{~km}$. This is unexpected because TSS should provide substrates for particle-attached bacteria, which are more productive than free-living bacteria on a per-cell basis (Crump et al. 1998). One possible explanation is that TSS in Chesapeake Bay is less labile in the winter to spring period than in summer when detrital organic matter comes from growing plants. This is in contrast to the findings of Findlay et al. (1991) who observed higher BP than phytoplankton production 
in the tidally influenced area of the Hudson River estuary from spring to fall. In the Hudson River, high TSS concentrations lead to rapid light attenuation, with diffuse attenuation coefficients reaching values of $10 \mathrm{~m}^{-1}$ during spring runoff (Cole et al. 1992). In contrast, the maximum coefficient measured in our study was $4.4 \mathrm{~m}^{-1}$ in early spring. In addition, dinoflagellates, which require strong stratification of the water column in order to use it as a migration pathway (Tyler \& Seliger 1978), would likely not be able to reach the oligohaline of the Hudson River estuary because the water column in the oligohaline is well mixed (Fisher et al. 1988). We therefore speculate that the smaller diffuse attenuation coefficient, strong stratification, and, possibly, more refractory TSS in the winter to spring period in Chesapeake Bay are key factors that promote higher GPP than BP in the oligohaline.

As with phytoplankton, bacteria originating from freshwater would likely suffer from osmotic stress. Painchaud et al. (1987) described massive losses of riverine bacteria as they flow into the salinity convergence zone in the St. Lawrence Estuary. This probable zone of high bacteria and phytoplankton mortality could provide an important source of organic matter for the ETM region. This idea is supported by the relationship between dissolved organic matter and salinity in the upper Chesapeake Bay, which is best fit with a convex second-order polynomial function (Fisher et al. 1998), indicating net dissolved organic matter production in the ETM region. This is in contrast to the idea that the production of dissolved organic matter in the ETM region is derived from bacterial colonization and dissolution of detritus from allochthonous sources. However, the insignificant relationship between BP and chlorophyllide $a$ (Table 2), an indicator of senescent diatoms, suggests that microbial communities did not appear to consume dissolved organic matter released from senescing diatoms, possibly because bacteria are also stressed by salinity changes along with phytoplankton. All of these lines of evidence suggest that the ETM region is an area of weak microbial heterotrophic activities and high salinity stress that causes the death of phytoplankton and bacteria, which increases dissolved organic matter concentrations.

\section{Phytoplankton pigment analyses}

Strong correlations were found between $R_{\text {comm }}$ and $\mathrm{chl} a$ and dinoflagellates; these strongly suggest that 'autotrophic organisms' were responsible for not only
GPP, but also a large fraction of $R_{\text {comm }}$ in the oligohaline region (Fig. 9, Table 2). These correlations could be caused by very tight coupling between autotrophic production and heterotrophic consumption, e.g. bacterial consumption of labile organic matter freshly released by phytoplankton. However, except in early spring, the high chl a concentrations downestuary of ETM were largely due to the presence of mixotrophic dinoflagellates. It therefore seems more likely that the combined autotrophic and heterotrophic capability of these dinoflagellates explains why there were such strong correlations between dinoflagellates, GPP and $R_{\text {comm }}$. Size-fractionated experiments also support this conclusion. A large fraction of $R_{\text {comm }}$ was due to organisms in the 3-10 $\mu \mathrm{m}$ size range in the south and ETM bottom water (Fig. 10) where approximately $68 \%$ of total chl a was found, which is consistent with a major contribution of mixotrophic dinoflagellates. The dinoflagellate Heterocapsa rotundatum, which was common in our samples, has an equivalent spherical diameter of $5.8 \mu \mathrm{m}$ (Jeong et al. 2005), and thus likely passed through the $10 \mu \mathrm{m}$ screen, but not through the $3 \mu \mathrm{m}$ screen.

Note that particle-attached bacteria can also contribute to respiration in the 3-10 $\mu \mathrm{m}$ fraction. To find the relative contribution of bacteria and dinoflagellates, we assumed that the bulk of respiration in the $<10 \mu \mathrm{m}$ size samples was from mixotrophic dinoflagellates and bacteria, and in the $<3 \mu \mathrm{m}$ size samples was only from bacteria. Then, we estimated that total bacteria contributed approximately 61 and $38 \%$ of total $R_{\text {comm }}$ in early spring and late spring, respectively. We also assumed that $85 \%$ of $R_{\text {comm }}$, which is the mean percentage of respiration rates of the $<10 \mu \mathrm{m}$ size samples (Fig. 10), is due to bacteria and dinoflagellates. Therefore, the contribution of mixotrophic dinoflagellates to $R_{\text {comm }}$ was approximately $24 \%$ in early spring and $47 \%$ in late spring. In early spring, dinoflagellate concentrations were the lowest and regression analysis also suggested that the contribution of dinoflagellates in explaining community metabolism was insignificant in early spring. However, the respiration of mixotrophic dinoflagellates was higher than that of the bacteria in late spring.

Our calculation of dinoflagellate contribution to $R_{\text {comm }}$ would be biased if the factor converting BP to BR were different for $<3$ and $>3 \mu \mathrm{m}$ bacteria. The conversion factor for the latter is presumably higher due to organic substrates on particles (Crump et al. 1998). To check the validity of this calculation, we estimated BGE of the bacterial community, which resulted in 0.18 in early spring and 0.19 in late spring. These BGE estimates fit well in the distribu- 
tion of BGE in the Chesapeake Bay (Apple et al. 2006), and they are consistent with the observation that BR increases with increasing temperature (Shiah \& Ducklow 1994), which apparently resulted in low BGE in spring. In addition, as discussed above, TSS might not be as labile, thus suppressing the metabolic activities of particle-attached bacteria in the ETM region, which is consistent with the fact that there was no significant correlation between total BP and TSS (Table 2). This evidence suggests that our assumption that different sizes of bacteria share the same respiration

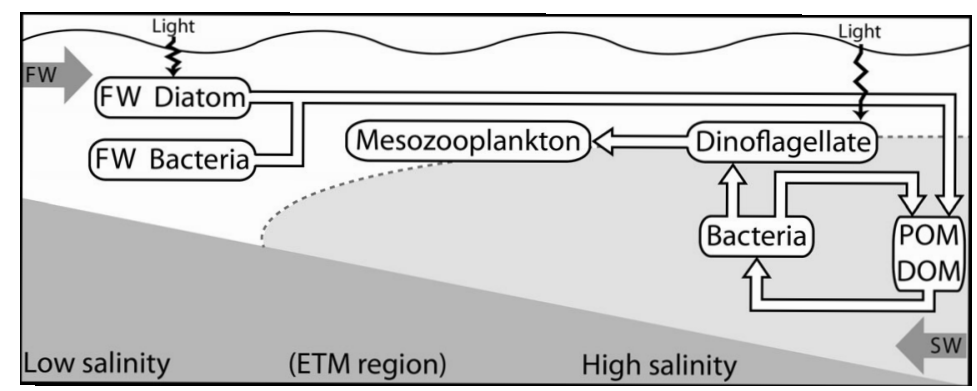

Fig. 11. Energy flow diagram illustrating the estuarine food web in the Chesapeake Bay estuarine turbidity maximum (ETM) region. FW: fresh water; SW: sea water; POM: particulate organic matter; DOM: dissolved organic matter; dotted line: pycnocline

efficiency is reasonable. However, BP and

BR are still expected to vary depending on river discharge, temperature, and the quality of organic matter. Therefore, we need further information on bacterial abundance in the 2 groups, the size of particle-attached bacteria, and the rate of bacterial metabolism with and without organic substrates to better define the contributions of bacteria and dinoflagellates to $R_{\text {comm }}$.

The high correlations between $R_{\text {comm }}$ and degraded phytoplankton pigments (except chlorophyllide a) also suggest that the rapid consumption of phytoplankton-derived organic matter resulted in increased $R_{\text {comm }}$ (Table 2). The distribution and concentration of pigment degradation products in the ETM region is very likely dictated by physiological stress, physical entrapment, and heterotrophic consumption (Lemaire et al. 2002). The different spatial distribution of chlorophyllide $a$, indicating senescent diatoms in contrast to other pheopigments, is consistent with the idea that diatoms experienced physiological stress (discussed above). That is, rapid salinity changes may play an important role in forming chlorophyllide $a$, perhaps due to the low tolerance of diatoms to salinity changes.

\section{Dinoflagellates and implications for the food web}

The ETM region of Chesapeake Bay is a mixing zone for a continuous supply of river-borne diatoms, inorganic and organic nutrients, bacteria, TSS, and highly productive estuarine dinoflagellates. Together, these materials provide carbon sources for omnivorous mesozooplankton (Fig. 11). We speculate that changes in salinity and other physical mechanisms break down and trap particulate and dissolved organic matter mainly from the Susquehanna River in the ETM region. Measured GPP, $R_{\text {comm }}$ and BP are

low in the ETM, suggesting that much of this organic matter passes through the ETM region to the south where it supports the growth of bacteria. The microbial community would be further supported by the input of inorganic and organic matter from the mesohaline region of the bay via landward-flowing bottom water.

We hypothesize that the bacteria, along with cryptophytes, are consumed by mixotrophic dinoflagellates, and that these dinoflagellates therefore play an important role in the food web by consuming organic matter from the detrital food web and also by fixing carbon and nutrients autotrophically. Dinoflagellates moving between the down-estuary region and the ETM could switch between heterotrophic and autotrophic modes of nutrition to maximize growth (Stoecker 1998). However, it should be noted that the time it takes to switch can vary depending on the mixotrophic species and also light, nutrient, and food availability (Sanders et al. 1990). It is also unclear whether or not the physiological change is unidirectional from heterotroph to autotroph. It is therefore probable that individual dinoflagellates possess different degrees of mixotrophic balance, from primarily heterotrophic to intermediate to primarily autotrophic. Regardless, the positive relationships between dinoflagellate pigments and both GPP and $R_{\text {comm }}$ during winter to spring suggest that dinoflagellates between 45 and $80 \mathrm{~km}$ performed photosynthesis and obtained energy by feeding heterotrophically on bacteria and cryptophytes.

The organic matter supply from diverse phytoplankton groups, bacteria, and external loading can give rise to abundant and diverse secondary producers. Mesozooplankton can fulfill their carbon requirements in ETM regions by selectively grazing on phytoplankton, by filtering out detrital organic 
matter, or by grazing on microzooplankton (Van den Meersche et al. 2009). The low GPP in the Chesapeake Bay ETM suggests that copepod diets would be composed of a variety of food items. However, dinoflagellates are estimated to have about twice the caloric content (the sum of protein, carbohydrate, and lipid) of diatoms of similar volume (Hitchcock 1982). Moreover, copepod egg production has been shown to be highly correlated with the ingestion of dinoflagellates (Kleppel et al. 1991). Also, due to the high grazing ability and preference for dinoflagellates by copepods, most dinoflagellate biomass is consumed in the water column and sinking loss to the bottom is negligible (Sellner et al. 1991, 1992). These facts, combined with the results from the present study, lead us to conclude that the Chesapeake Bay ETM region is an area of relatively low microbial activity and high dinoflagellate productivity that directly supports mesozooplankton and higher trophic levels rather than being an area supporting a high efficiency 'microbial shunt.'

Acknowledgements. We thank the captain and crew of the RV 'Hugh R. Sharp' for their assistance on the research cruises to the Chesapeake Bay ETM. We also thank E. Houde, M. Roman, L. Sanford, E. North, J. Pierson, S-Y. Chao, D. Kimmel, Y. Kim, S. Suttles, E. Kiss, and all of the members of the BITMAXII project for their assistance in collecting water samples and analyzing data. We are especially grateful to L. Codispoti and V. Kelly for providing D.Y.L. with training in high precision oxygen measurement methods. This work was supported by the National Science Foundation (Grant OCE-0453905). This is UMCES contribution no. 4631 .

\section{LITERATURE CITED}

Adolf JE, Yeager CL, Miller WD, Mallonee ME, Harding LW Jr (2006) Environmental forcing of phytoplankton floral composition, biomass, and primary productivity in Chesapeake Bay, USA. Estuar Coast Shelf Sci 67: 108-122

Apple JK, del Giorgio PA, Kemp WM (2006) Temperature regulation of bacterial production, respiration, and growth efficiency in a temperate salt-marsh estuary. Aquat Microb Ecol 43:243-254

Arar EJ, Collins GB (1997) In vitro determination of chlorophyll $a$ and pheophytin $a$ in marine and freshwater algae by fluorescence. Method 445.0, US Environmental Protection Agency, Cincinnatti, $\mathrm{OH}$

> Arhonditsis GB, Paerl HW, Valdes-Weaver LM, Stow CA, Steinberg LJ, Reckhow KH (2007) Application of Bayesian structural equation modeling for examining phytoplankton dynamics in the Neuse River Estuary (North Carolina, USA). Estuar Coast Shelf Sci 72:63-80

> Azam F, Fenchel T, Field JG, Gray JS, Meyer-Reil LA, Thingstad F (1983) The ecological role of water-column microbes in the sea. Mar Ecol Prog Ser 10:257-263
Baross JA, Crump BC, Simenstad CA (1994) Elevated 'microbial loop' activities in the Columbia River estuarine turbidity maximum. In: Dyer KR, Orth RJ (eds) Changes in fluxes in estuaries: implications from science to management. ECSA/ERF symposium. Olsen \& Olsen, Fredenborg, p 459-464

> Boak AC, Goulder R (1983) Bacterioplankton in the diet of the calanoid copepod Eurytemora sp. in the Humber Estuary. Mar Biol 73:139-149

> Brand LE (1984) The salinity tolerance of forty-six marine phytoplankton isolates. Estuar Coast Shelf Sci 18: 543-556

Buchanan TJ, Somers WP (1969) Discharge measurements at gaging stations: U.S. Geological Survey techniques of water-resources investigations, Book 3, Chapter A8. USGS, Washington, DC

Caffrey JM (2004) Factors controlling net ecosystem metabolism in U.S. estuaries. Estuaries 27:90-101

Carpenter JH (1965) The accuracy of the Winkler method for dissolved oxygen analysis. Limnol Oceanogr 10:135-140

Carpenter SR, Cole JJ, Pace ML, Van de Bogert M and others (2005) Ecosystem subsidies: terrestrial support of aquatic food webs from ${ }^{13} \mathrm{C}$ addition to contrasting lakes. Ecology 86:2737-2750

Chatterjee S, Hadi AS (2006) Regression analysis by example, 4th edn. John Wiley and Sons, Hoboken, NJ

$>$ Cloern JE, Alpine AE, Cole BE, Wong RLJ, Arthur JF, Ball MD (1983) River discharge controls phytoplankton dynamics in the northern San Francisco Bay estuary. Estuar Coast Shelf Sci 16:415-426

Cole JJ, Caraco NF, Peierls BL (1992) Can phytoplankton maintain a positive carbon balance in a turbid, freshwater, tidal estuary? Limnol Oceanogr 37:1608-1617

Crump BC, Baross JA, Simenstad CA (1998) Dominance of particle-attached bacteria in the Columbia River estuary, USA. Aquat Microb Ecol 14:7-18

> Crump BC, Peranteau C, Beckingham B, Cornwell JC (2007) Respiratory succession and community succession of bacterioplankton in seasonally anoxic estuarine waters. Appl Environ Microbiol 73:6802-6810

> Findlay S, Pace ML, Lints D, Cole JJ, Caraco NF, Peierls B (1991) Weak coupling of bacterial and algal production in a heterotrophic ecosystem: the Hudson River estuary. Limnol Oceanogr 36:268-278

> Fisher TR, Harding LW Jr, Stanley DW, Ward LG (1988) Phytoplankton, nutrients, and turbidity in the Chesapeake, Delaware and Hudson estuaries. Estuar Coast Shelf Sci 27:61-93

Fisher TR, Hagy JD, Rochelle-Newall E (1998) Dissolved and particulate organic carbon in Chesapeake Bay. Estuaries 21:215-229

- Fisher TR, Gustafson AB, Sellner K, Lacouture R and others (1999) Spatial and temporal variation of resource limitation in Chesapeake Bay. Mar Biol 133:763-778

> Harding LW Jr (1988) The time-course of photoadaptation to low-light in Prorocentrum mariae-lebouriae (Dinophyceae). J Phycol 24:274-281

> Harding LW Jr (1994) Long-term trends in the distribution of phytoplankton in Chesapeake Bay: roles of light, nutrients and streamflow. Mar Ecol Prog Ser 104:267-291

> Harding LW Jr, Meeson BW, Fisher TR (1986) Phytoplankton production in two East Coast estuaries: photosynthesislight functions and patterns of carbon assimilation in Chesapeake and Delaware Bays. Estuar Coast Shelf Sci 23:773-806 
Heinle DR, Harris RP, Ustach JF, Flemer DA (1977) Detritus as food for estuarine copepods. Mar Biol 40:341-353

Hitchcock GL (1982) A comparative study of the size-dependent organic composition of marine diatoms and dinoflagellates. J Plankton Res 4:363-377

Hopkinson CS, Vallino JJ (1995) The relationships among man's activities in watersheds and estuaries: a model of runoff effects on patterns of estuarine community metabolism. Estuaries 18:598-621

> Hopkinson CS Jr, Sherr B, Wiebe WJ (1989) Size fractionated metabolism of coastal microbial plankton. Mar Ecol Prog Ser 51:155-166

> Ichinomiya $M$, Nakamachi $M$, Honda $M$, Fukuchi $M$, Taniguchi A (2009) Role of heterotrophic dinoflagellates in the fate of diatoms released from fast ice in coastal water of Lützow-Holm Bay, East Antarctica. Mar Ecol Prog Ser 383:27-36

- Iriberri J, Unanue M, Ayo B, Barcina I, Egea L (1990) Bacterial production and growth rate estimation from $\left[{ }^{3} \mathrm{H}\right]$ thymidine incorporation for attached and free-living bacteria in aquatic systems. Appl Environ Microbiol 56: 483-487

> Irigoien X, Castel J (1997) Light limitation and distribution of chlorophyll pigments in a highly turbid estuary: the Gironde (SW France). Estuar Coast Shelf Sci 44:507-517

> Jeong HJ, Park JY, Nho JH, Park MO and others (2005) Feeding by red-tide dinoflagellates on the cyanobacterium Synechococcus. Aquat Microb Ecol 41:131-143

Kemp WM, Sampou PA, Garber J, Tuttle J, Boynton WR (1992) Seasonal depletion of oxygen from bottom waters of Chesapeake Bay: roles of benthic and planktonic respiration and physical exchange processes. Mar Ecol Prog Ser 85:137-152

Kemp WM, Smith EM, Marvin-Dipasquale M, Boynton WR (1997) Organic carbon balance and net ecosystem metabolism in Chesapeake Bay. Mar Ecol Prog Ser 150: $229-248$

Kemp WM, Boynton WR, Adolf JE, Boesch DF and others (2005) Eutrophication of Chesapeake Bay: historical trends and ecological interactions. Mar Ecol Prog Ser 303:1-29

Kimmel DG, Roman MR (2004) Long-term trends in mesozooplankton abundance in Chesapeake Bay, USA: influence of freshwater input. Mar Ecol Prog Ser 267:71-83

Kirchman DL (1993) Leucine incorporation as a measure of biomass production by heterotrophic bacteria. In: Kemp PF, Sherr BF, Sherr EB, Cole JJ (eds) Handbook of methods in aquatic microbial ecology. Lewis Publishers, Boca Raton, FL, p 509-512

> Kleppel GS, Holliday DV, Pieper RE (1991) Trophic interactions between copepods and microplankton: a question about the role of diatoms. Limnol Oceanogr 36:172-178

Lemaire E, Abril G, De Wit R, Etcheber H (2002) Distribution of phytoplankton pigments in nine European estuaries and implications for an estuarine typology. Biogeochemistry 59:5-23

> Li M, Zhong L, Boicourt WC (2005) Simulations of Chesapeake Bay estuary: sensitivity to turbulence mixing parameterizations and comparison with observations. J Geophys Res 110:C12004, doi:10.1029/2004JC002585

- Malone TC, Kemp W, Ducklow H, Boynton W, Tuttle J, Jonas R (1986) Lateral variation in the production and fate of phytoplankton in a partially stratified estuary. Mar Ecol Prog Ser 32:149-160
Muylaert K, Sabbe K, Vyverman W (2000) Spatial and temporal dynamics of phytoplankton communities in a freshwater tidal estuary (Schelde, Belgium). Estuar Coast Shelf Sci 50:673-687

> North EW, Houde ED (2006) Retention mechanisms of white perch (Morone americana) and striped bass (Morone saxatilis) early-life stages in an estuarine turbidity maximum: an integrative fixed-location and mapping approach. Fish Oceanogr 15:429-450

Pace ML, Carpenter SR, Cole JJ, Coloso JJ and others (2007) Does terrestrial organic carbon subsidize the planktonic food web in a clear-water lake? Limnol Oceanogr $52: 2177-2189$

Painchaud J, Lefaivre D, Therriault JC (1987) Box model analysis of bacterial fluxes in the St. Lawrence Estuary. Mar Ecol Prog Ser 41:241-252

> Park K, Wang HV, Kim SC, Oh JH (2008) A model study of the estuarine turbidity maximum along the main channel of the upper Chesapeake Bay. Estuaries Coasts 31: 115-133

Parsons TR, Takahashi M, Hargrave B (1984) Biological oceanographic processes, 3rd edn. Pergamon Press, New York, NY

Pomeroy LR (1974) The ocean's food web, a changing paradigm. Bioscience 24:499-504

Roman MR, Holliday DV, Sanford LP (2001) Temporal and spatial patterns of zooplankton in the Chesapeake Bay turbidity maximum. Mar Ecol Prog Ser 213:215-227

Sampou P, Kemp WM (1994) Factors regulating plankton community respiration in Chesapeake Bay. Mar Ecol Prog Ser 110:249-258

Sanders RW (1991) Mixotrophic protists in marine and freshwater ecosystems. J Eukaryot Microbiol 38:76-81

Sanders RW, Porter KG, Caron DA (1990) Relationship between phototrophy and phagotrophy in the mixotrophic chrysophyte Poterioochromonas malhamensis. Microb Ecol 19:97-109

Sanford LP, Suttles SE, Halka JP (2001) Reconsidering the physics of the Chesapeake Bay estuarine turbidity maximum. Estuaries 24:655-669

- Schubel JR, Pritchard DW (1986) Responses of upper Chesapeake Bay to variations in discharge of the Susquehanna River. Estuaries 9:236-249

Sellner KG, Lacouture RV, Cibik SJ, Brindley A, Brownlee SG (1991) Importance of a winter dinoflagellatemicroflagellate bloom in the Patuxent River estuary. Estuar Coast Mar Sci 32:27-42

Sellner KG, Sawangwong P, Dawson R, Boynton WR, Kemp WM, Garber JH (1992) Fate of dinoflagellates in Chesapeake Bay: Is sedimentation likely? In: Smayda TJ (ed) Marine phytoplankton. Elsevier, New York, NY, p 825-830

Shiah FK, Ducklow HW (1994) Temperature regulation of heterotrophic bacterioplankton abundance, production, and specific growth rate in Chesapeake Bay. Limnol Oceanogr 39:1243-1258

Simon M, Grossart HP, Schweitzer B, Ploug H (2002) Microbial ecology of organic aggregates in aquatic ecosystems. Aquat Microb Ecol 28:175-211

> Smith EM, Kemp WM (1995) Seasonal and regional variations in plankton community production and respiration for Chesapeake Bay. Mar Ecol Prog Ser 116:217-231

Smith EM, Kemp WM (2001) Size structure and the production/respiration balance in a coastal plankton community. Limnol Oceanogr 46:473-485 
Smith EM, Kemp WM (2003) Planktonic and bacterial respiration along an estuarine gradient: responses to carbon and nutrient enrichment. Aquat Microb Ecol 30:251-261

Stoecker DK (1998) Conceptual models of mixotrophy in planktonic protists and some ecological and evolutionary implications. Eur J Protistol 34:281-290

Stoecker DK, Li A, Coats DW, Gustafson DE, Nannen MK (1997) Mixotrophy in the dinoflagellate Prorocentrum minimum. Mar Ecol Prog Ser 152:1-12

Tyler MA, Seliger HH (1978) Annual subsurface transport of a red tide dinoflagellate to its bloom area: water circulation patterns and organism distributions in the Chesapeake Bay. Limnol Oceanogr 23:227-246

Van den Meersche K, Van Rijswijk P, Soetaert K, Middel-

Editorial responsibility: Antonio Bode,

A Coruña, Spain burg JJ (2009) Autochthonous and allochthonous contributions to mesozooplankton diet in a tidal river and estuary: integrating carbon isotope and fatty acid constraints. Limnol Oceanogr 54:62-74

Van Heukelem L, Thomas CS (2001) Computer-assisted high-performance liquid chromatography method development with applications to the isolation and analysis of phytoplankton pigments. J Chromatogr A 910:31-49

> Wofsy SC (1983) A simple model to predict extinction coefficients and phytoplankton biomass in eutrophic waters. Limnol Oceanogr 28:1144-1155

$>$ Xu J, Hood RR, Chao SY (2005) A simple empirical optical model for simulating light attenuation variability in a partially mixed estuary. Estuaries 28:572-580

Submitted: February 23, 2011; Accepted: December 5, 2011 Proofs received from author(s): February 29, 2012 